\title{
Mineralogi og geokemi af det Øvre Miocæne Gram ler
}

\section{Af Erik Skovbjerg Rasmussen og Ole Hede Larsen}

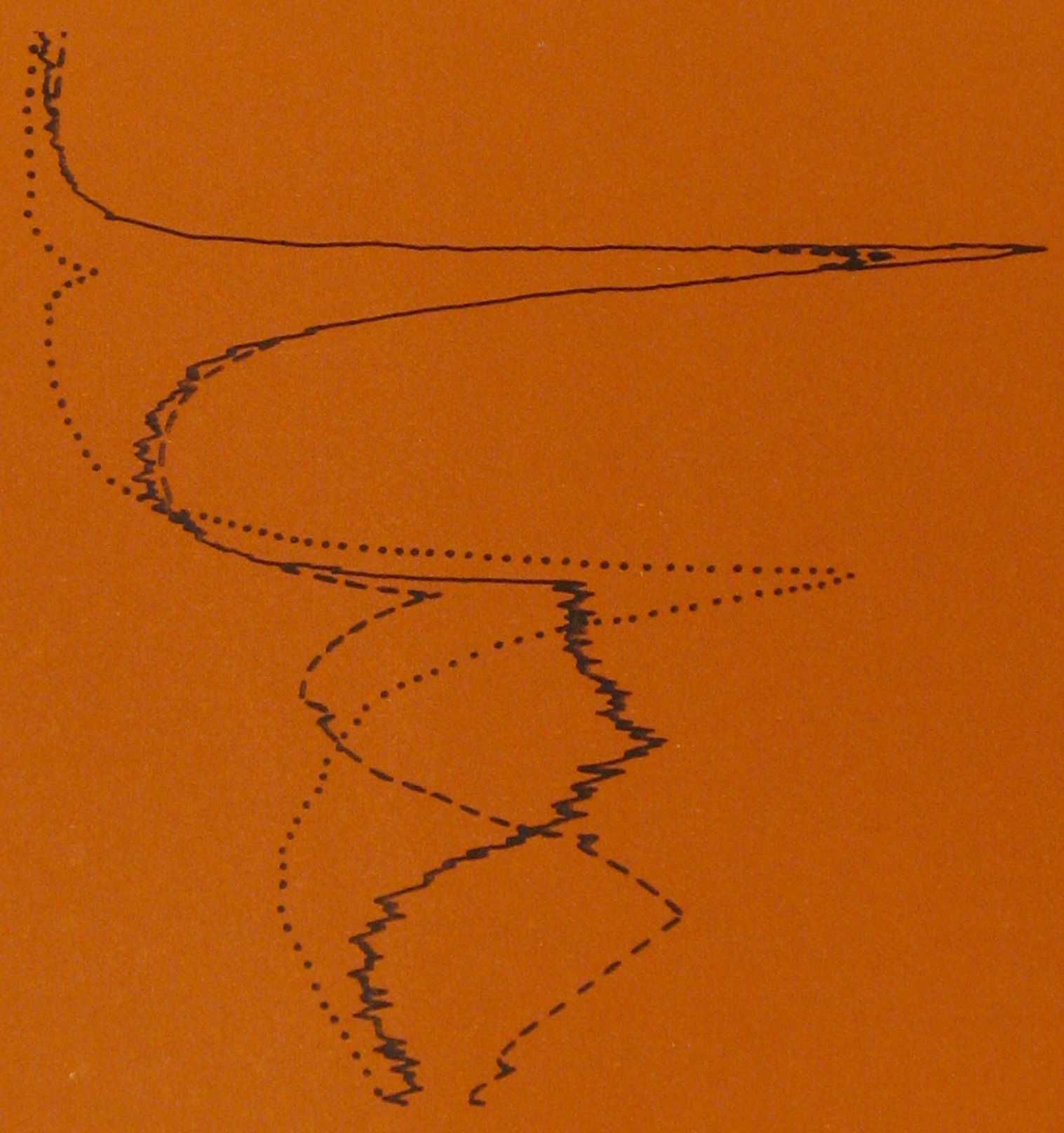

\section{ज्या}

Danmarks Geologiske Undersøgelse 


\section{Mineralogi og geokemi af det Øvre Miocæne Gram ler}

\section{Af Erik Skovbjerg Rasmussen og Ole Hede Larsen}

Undersøgelser udført for

Midtsønderjyllands Museum i Gram

Juni 1989

DGU serie D nr. 7 
Nøgleord: Øvre Miocæn, Nordsø bassin, mineralogi, geokemi, kildeområde, aflejringsmiljø, lerbjergarter, diagenese.

Med to tavler.

Vignet: Udsnit af Rontgendiffraktogram der viser lermineralogi $i$ en prove.

DGU Serie D nr. 7

ISBN 87-88640-41-8

ISSN 0900-6257

Oplag: $500 \mathrm{ex}$.

Tryk: DGU

Dato: 1989-08-01

Manuskript modtaget: 1987-05-04

Accepteret: 1989-01-13

Tegning: Helle zetterwall

Foto: M. Abrahamsen og B. Scharck

Forfattere: Erik Skovbjerg Rasmussen

Danmarks Geologiske Undersøgelse

Thoravef 8, 2400 Robenhavn NV.

Ole Hede Larsen

Burmeister \& Wain Energi A/S

Teknikerbyen 23

2830 virum

Redaktør: Peter Frykman

- Danmarks Geologiske Undersøgelse

Thoravef 8, 2400 Kobenhavn NV 
SAMMENDRAG............................. 5 ABSTRACT ................................

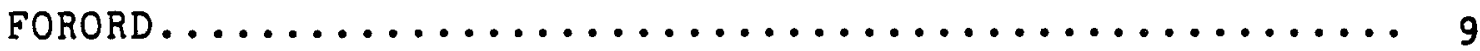

INDLEDNING.............................. 11

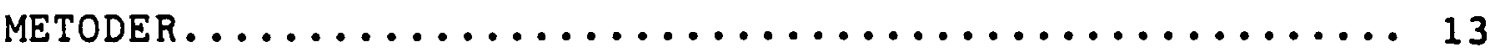

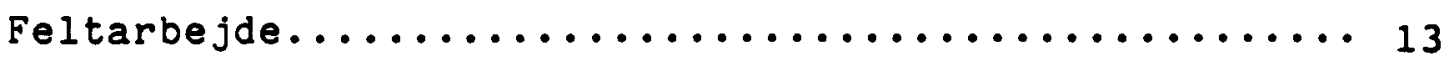

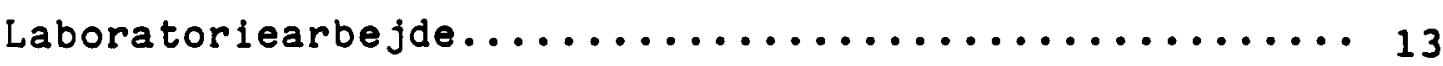

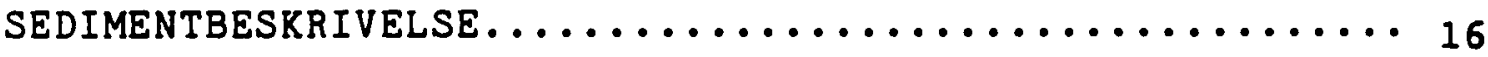

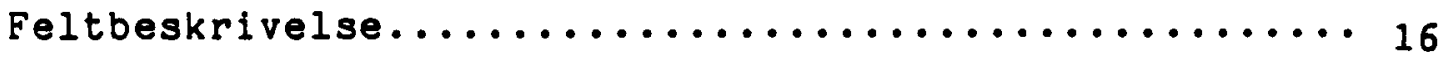

Mikroskopisk beskrivelse..................... 18

Generel beskrivelse...................... 18

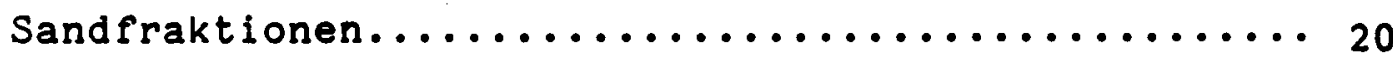

Gravegange............................ 20

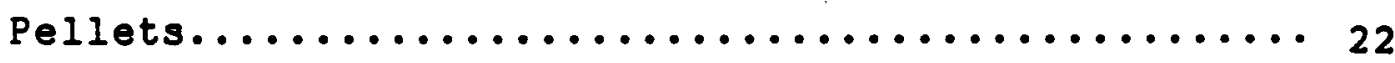

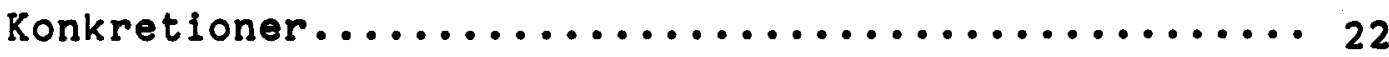

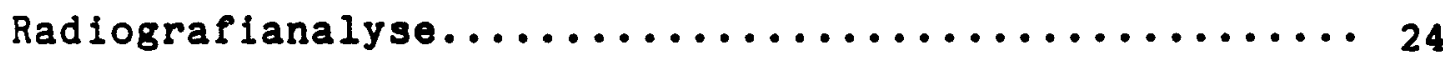

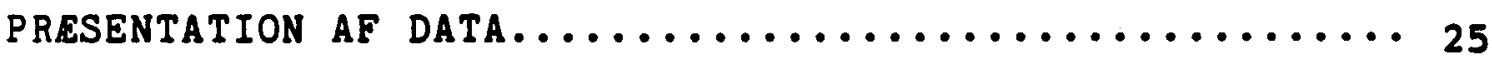

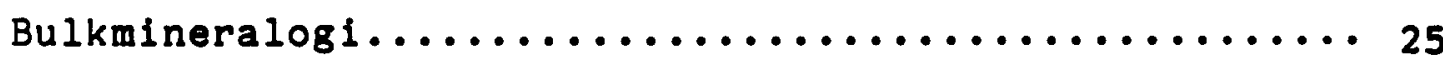

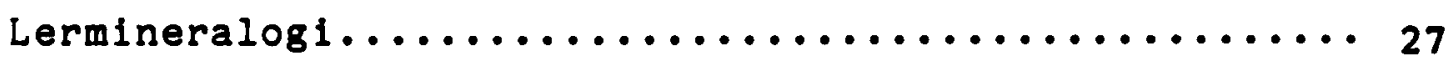

Geokemi............................... 27

Bulkmineralogi af finsandslagene.............. 29

Bulkmineralogi af konkretioner................ 30

Kornstørrelsesanalyse..................... 30 


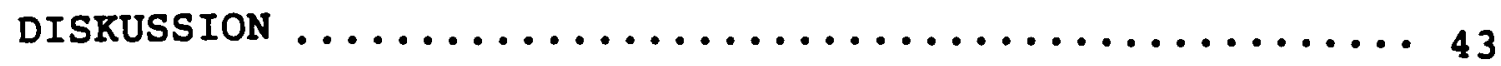

Kildeområde...........................4 44

Aflejringsmiljø......................... 46

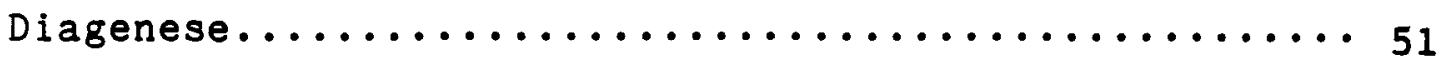

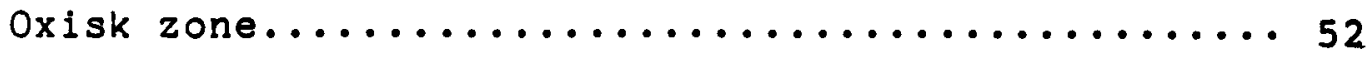

Anoxisk sulfidisk zone.................... 52

Anoxisk metanisk zone..................... 54

KONKLUSION................................. 57

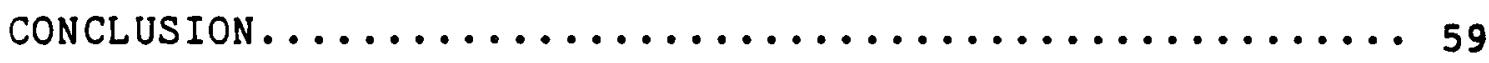

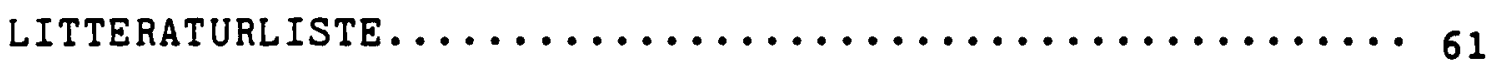

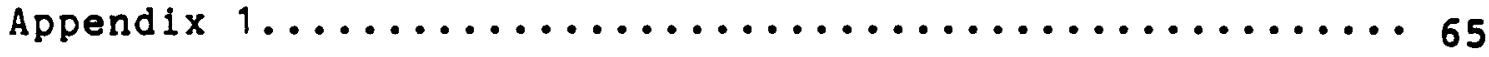

Metodebeskrivelse.......................... 65

Kornstørrelsesanalyse........................65 65

Bulkmineralogisk analyse.................... 66

Lermineralogisk analyse.....................6.67

Geokemi.................................6n

Radiografi............................ 71

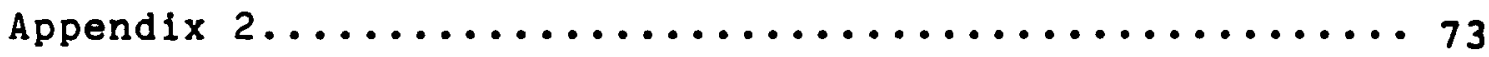

Tabeller................................ 74

A. Bulkmineralogi........................ 74

B. Lermineralogi.......................... 75

C. Geokemi............................... 76

D. Kornstørrelsesanalyse.................... 77 
Det Фvre miocæne Gram ler ved Gram Teglværk er unders $\phi g t$. Et $13 \mathrm{~m}$ højt profil er beskrevet og 27 prøver analyseret for mineralogi, kornstørrelse samt organisk kulstof og svovl. Endvidere er seks prøver analyseret for $\mathrm{Ca}, \mathrm{Mg}, \mathrm{Mn}, \mathrm{K}, \mathrm{Fe}$, $\mathrm{Na}$ og Al.

Sedimentet består af glimmerholdigt siltet ler med en generel stigende kornstørrelse opad $i$ profilet og $\phi v e r s t$ erkendes to stormlag af lamineret finsand. Nederst i profilet findes fem horisonter af siderit-og calcitkonkretioner.

Gram leret er aflefret pa shelfen i det tertiare Nordsebassin. En vesentlig del af materialet er aflejret under relativt høje energiforhold i forbindelse med stormsituationer og det mest finkornede materiale or aflejret fra suspension. Den nederste del af den undersøgte sekvens er aflejret fjernest fra kysten med dominans af finkornede materialer aflejret fra suspension og enkelte distale stormlag. Sedimentet fremtræder i dag homogent p.g.a. bioturbation. De to stormlag overst $i$ profilet er aflejret pá dybder over stormbølgebasis. Hele sekvensen afspejler en regressiv udvikling.

Den diagenetiske udvikling er karakteriseret ved ophold $i$ tre zoner, der er relateret til nedbrydningsprocesser af det organiske materiale. I den oxiske zone er der dannet mindre mængder glaukonit i fækale pellets. Anoxiske sulfidiske forhold er opnáet relativt hurtigt p.g.a. høj aflejringsrate og højt indhold af organisk materiale. I denne zone dannedes pyrit og Fe-fattige karbonater. Pá større indsynkningsdybde etableredes anoxiske metaniske forhold, hvor udfaldning af Fe-rige karbonater er foregat. 
The Upper Miocene Gram Clay at Gram Brickworks has been investigated. A $13 \mathrm{~m}$ profile has been described and analysed. This includes determination of mineralogy, grain size and organic carbon and sulphur in 27 samples and determination of $\mathrm{Ca}, \mathrm{Mg}, \mathrm{Mn}, \mathrm{K}, \mathrm{Fe}, \mathrm{Na}$ and $\mathrm{Al}$ in 6 samples.

The sediment is a micaceous silty clay, with upwards increasing grain size and at the top two sandy storm layers were identified. In the lower part of the sequence five horizons of concretions occur.

The Gram Clay was deposited on the shelf. A great part of the material was deposited at relatively high energy conditions in connection with storm situations, and the most finegrained material was deposited from suspension. The lower part of the investigated sequence was deposited most distant from the coast, with dominance of finegrained material deposited from suspension and only minor parts as distal storm layers. The sediments were subsequently homogenized due to bioturbation. The storm layers at the top were deposited above stormwave basis. The sediments reflects a regressive depositional sequence.

The diagenetic evolution was characterized by residence within three depth zones related to processes of degradation of organic matter. Some glauconite was formed within the oxic zone, in feacal pellets. Anoxic sulphidic conditions were established relative early due to high rate of deposition and high content of organic matter. In this zone pyrite and Fe-poor carbonates were formed. At greater depth of burial, anoxic methanic conditions were established with precipitation of Fe-rich carbonates. 
FORORD

Nærværende publikation er baseret på en sedimentologisk undersøgelse af Gram leret ved Gram Teglværk, udarbejdet i vinteren 1985-86 for Midtsønderjyllands Museum i Gram. 


\section{INDLEDNING}

Nærværende rapport omhandler en sedimentologisk og geokemisk unders $\emptyset$ gelse af Gram leret på typelokaliteten ved Gram teglværk.

Gram leret er en del af den marine, øvre miocæne Gram Formation. Formationen består nederst af ca. 3 meter glaukonit ler, der følges af det omtalte Gram ler med en mægtighed på gennemsnitlig 24 meter og øverst følger ca. 5 meter Gram silt (Rasmussen 1961, 1979).

Glaukonit leret og den basale del af Gram leret, der nederst ofte indeholder goethitiserede glaukonitkorn, er aflejret $i$ et lavmarint og, især $i$ den nedre del af Gram leret, energirigt miljø (Dinesen 1976).

Gram leret er et hovedsagligt leret og siltet sediment og er aflejret under mere energifattige forhold og på større dybde. Rasmussen (1966) foreslàr en dybde på ca. 50 meter.

Under aflejringen af Gram siltet steg energiniveauet atter i miljøet.

I figur 1 ses udbredelsen af Gram Formationen i Danmark og lokaliseringen af den unders $\emptyset$ gte sekvens. 


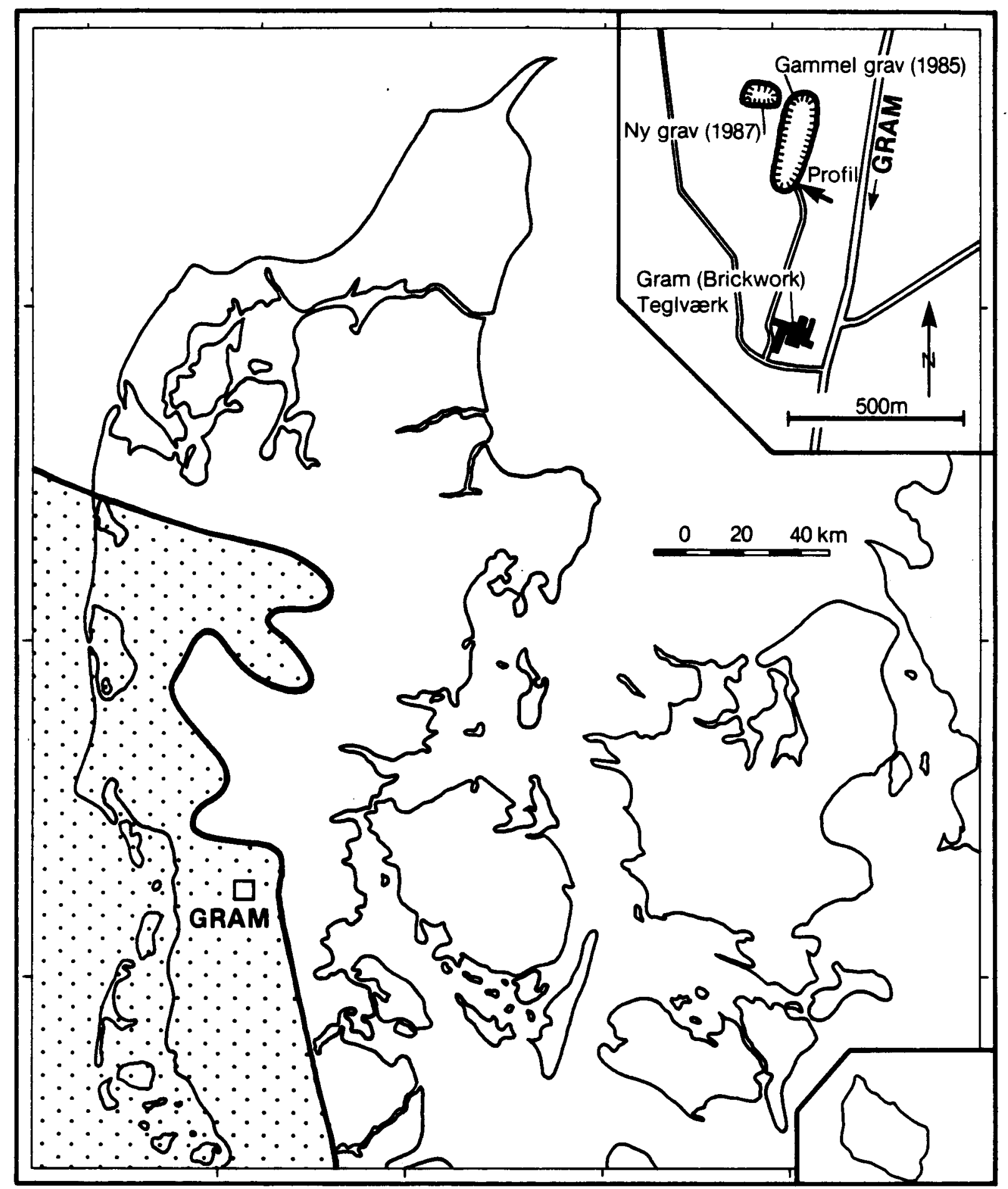

Fig. 1. Kort der viser lokaliteten med det unders $₫$ gte profil med udbredelsen af Gram Formationen (prikket) i Danmark (efter Rasmussen, 1966).

Fig. 1. Map showing the investigated profile at Gram and the distribution of the Gram Formation (shaded) in Denmark (From Rasmussen, 1966). 
I figur 2 ses en skematisk oversigt over arbejdsforløbet i unders $\emptyset$ gelsen.

Feltarbejde

Profilet er beskrevet makroskopisk i felten, herefter er der indsamlet provemateriale for hver halve meter i det ca. 13 meter høje profil. Endvidere er der udtaget prøvemateriale til bulkanalyse fra fire konkretioner of 2 siltlag.

Laboratoriearbejde

Prøverne er beskrevet i binoculart mikroskop, herefter er der udtaget en passende mængde prøvemateriale til videre forarbejdning. Den iltede overflade er bortskåret og en del af materialet er tørret ved $105^{\circ} \mathrm{C}$ natten over. Herefter knustes det $i$ en Wolfram-Carbidmorter. Pulveret er brugt til bulkmineralogisk og totalkemisk analyse. Ca. 5 gram blev afvejet og tørret $i \quad 3$ døgn ved $55^{\circ}$ C. De tørrede prøver er blevet vejet til bestemmelse af vandindholdet $i$ sedimentet. Disse prøver anvendtes til kornstørrelsesanalyse og lerfraktionen anvendtes til analyse af lermineralogi.

Et eksempel pá bulkmineralogisk og lermineralogisk analyse ses på figur 3 . 
Endvidere er der fremstillet 6 uforstyrrede prøver til en radiografiunders $\emptyset$ gelse.

En mere udforlig beskrivelse af metoderne findes i Appendix 1.

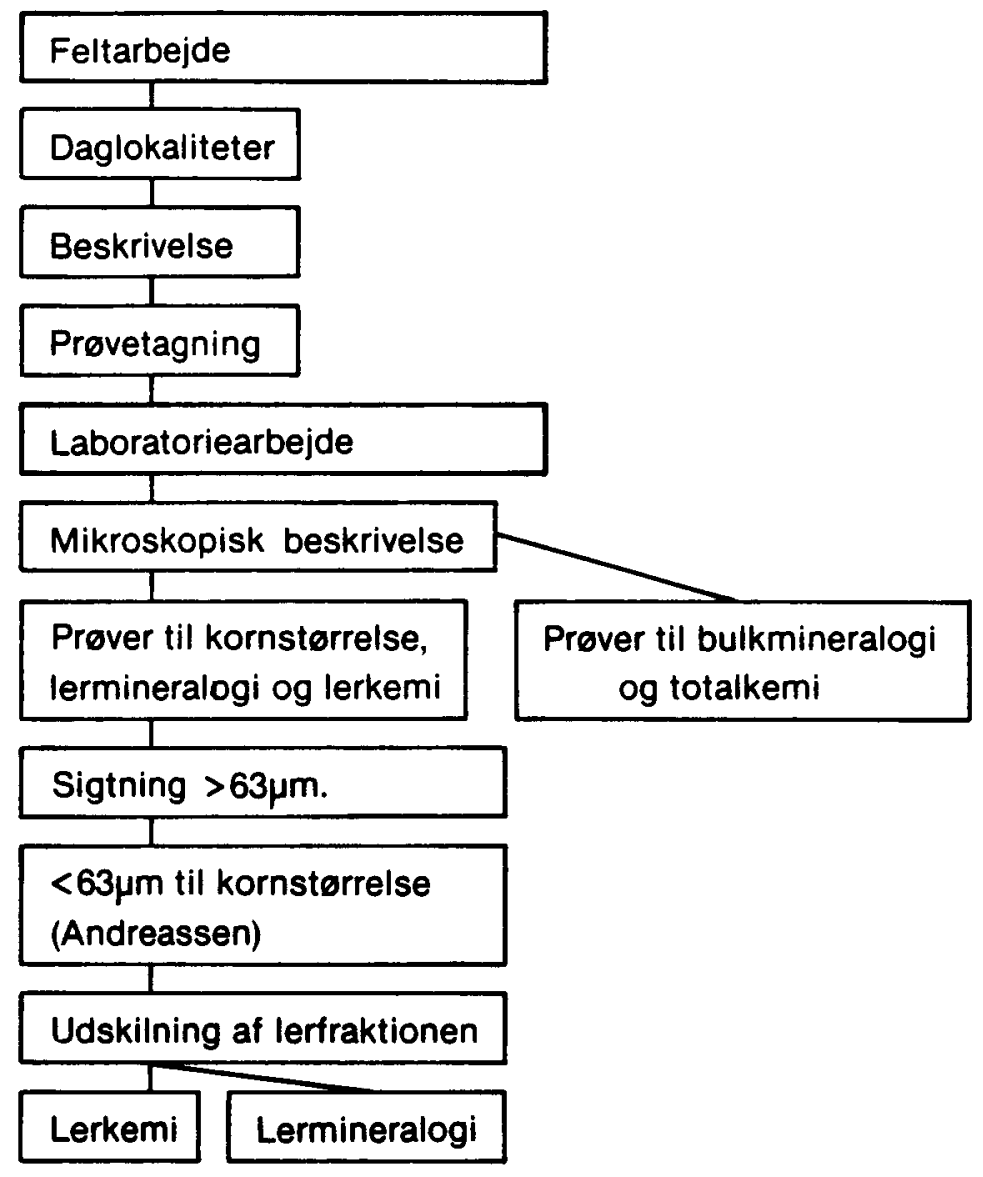

Fig. 2. Diagram over arbejdsproceduren.

Fig. 2. Diagram showing the methods of investigation.

Fig. 3 - se naste side;

Fig. 3 - next page.

Fig. 3. Eksempler pá røntgendiffraktogrammer (prøve G-10). A: Bulkmineralogi med angivelse af gitterplansafstand (d i A) og tilhørende mineralnavn og krystalplan. B: Lermineralogi (ubehandlet, glycolleret og varmebehandlet) med angivelse af gitterplansafstand ( $d$ i $A$ ).

Fig. 3 Examples of X-ray diffraktograms (sample G-10). A: Bulk mineralogy with statement of distance between lattice layers ( $d$ in $\AA$ ) and the proper mineral names and lattice layers. B: Clay mineralogy (untreated, ethylen glycolated, and heat treated) with statement of distance between lattice layers. 


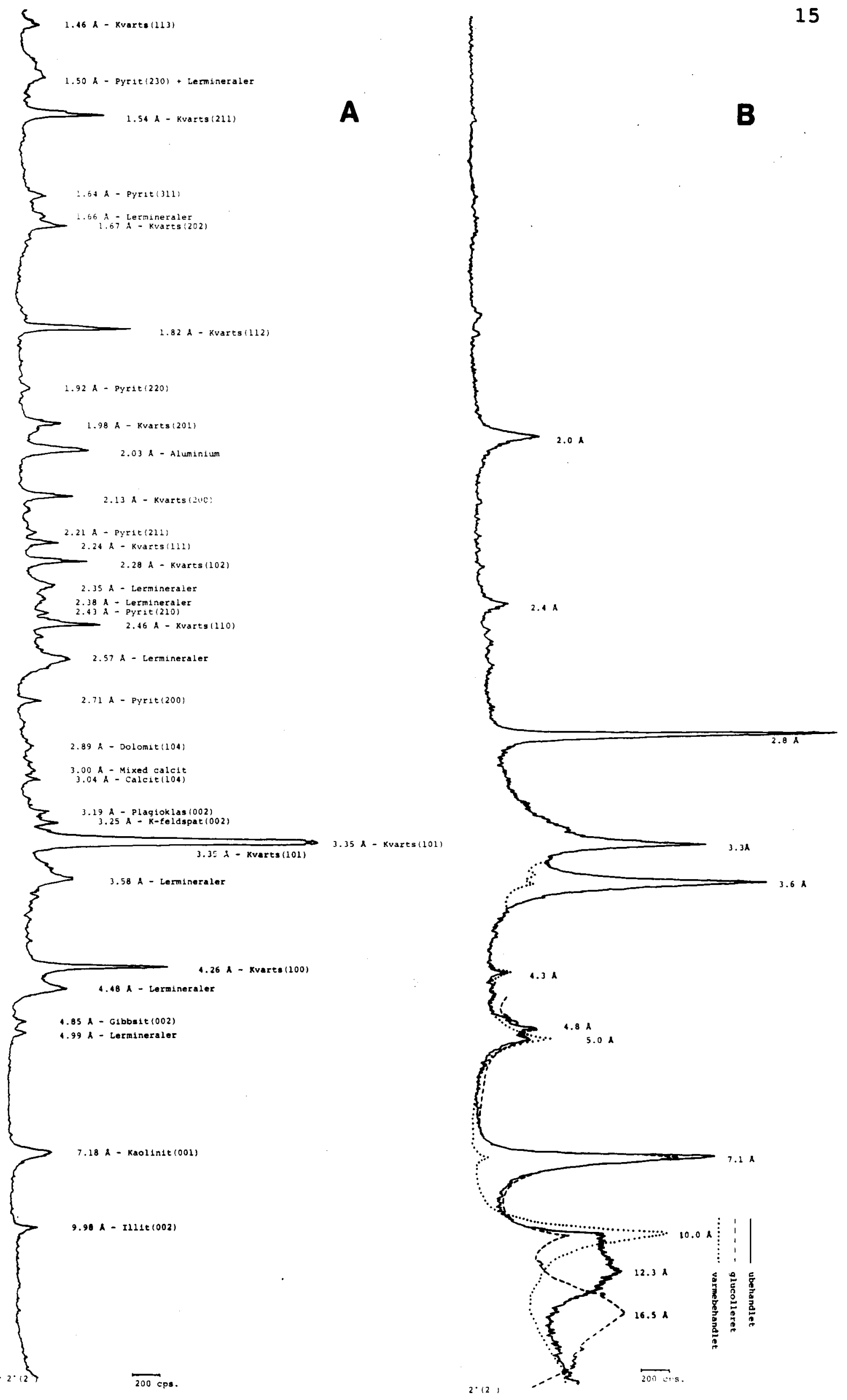

fig. 3 


\section{Feltbeskrivelse}

Profilet er ca. 13 meter højt (fig. 4). Sedimentet bestàr af en mørk gulligbrun, fed, glimmerholdig, siltet lerbjergart, der er mørkegrå i iltet tilstand.

I de nederst 5 meter forekommer 4-5 konkretionshorisonter.Konkretionerne er lys gulligbrune med ellipsoide former. Indvendigt ses ofte aftryk af krabber, omgivet af et sort, fedtet materiale.

Opad i profilet stiger siltindholdet, og ca. 1 meter under kvartærgrænsen ses 2 laminerede finsandslag med erosive baser og tykkelser op til 5 centimeter.

Den $\emptyset$ verste meter virker igen meget leret. Her er den oftest rustfarvet af jernudfældninger, der stammer fra de rødder som gennemtrænger sedimentet.

Grænsen til de kvartære materialer er skarp og erosiv.

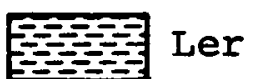

Silt/finsand
Oo Konkretioner

$\downarrow$ Moræneler

Legende til lithologiske logs.

Legend for lithological logs. 


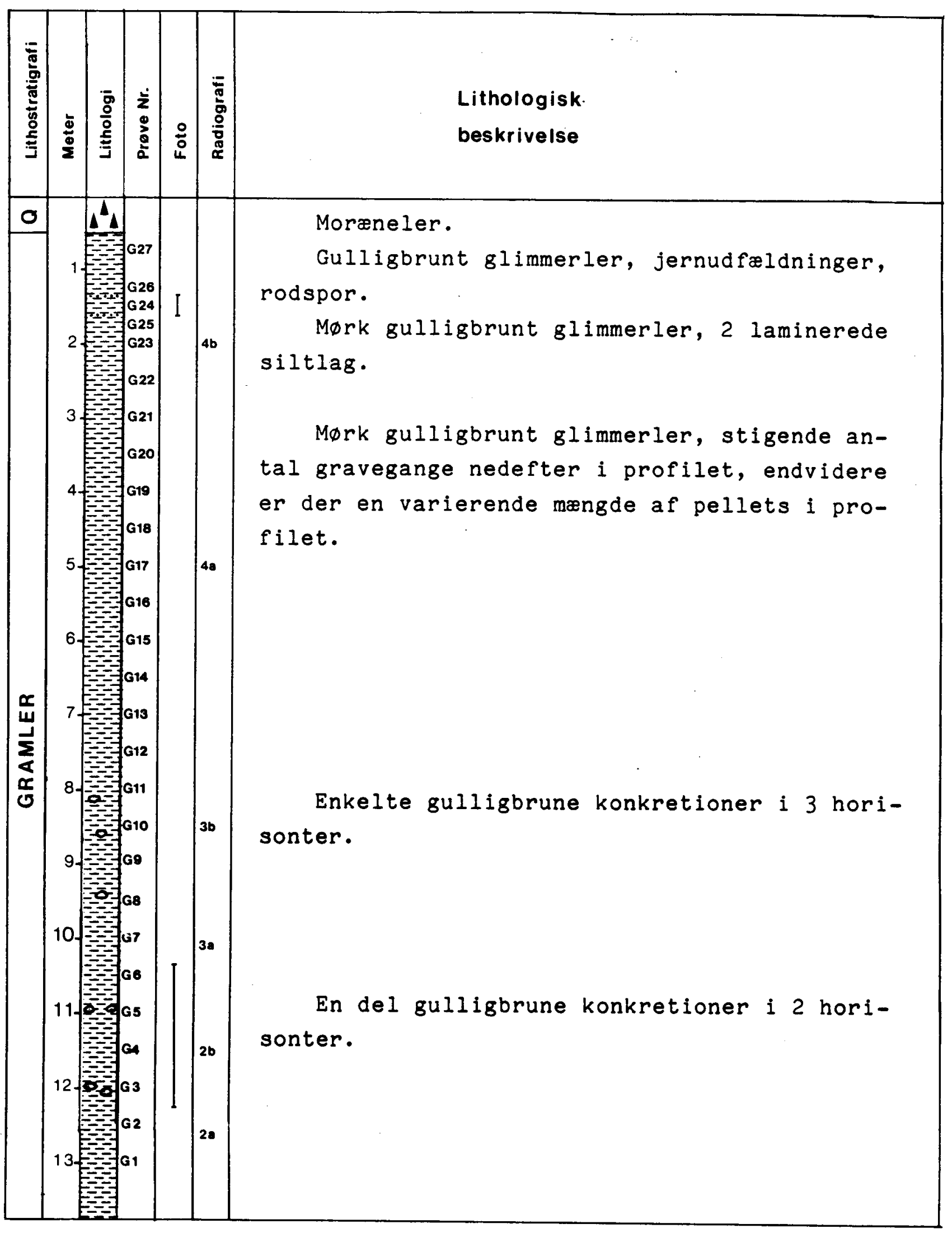

Fig. 4. Lithologisk log over det undersøgte profil. Fig. 4. Lithological log for the investigated profile. 
Mikroskopisk beskrivelse.

Generel beskrivelse

Der er ialt beskrevet 27 prøver. Prøverne 25, 26 og 27 er taget fra et nyt profil ca. $10 \mathrm{~m}$ syd for hovedprofilet. Til beskrivelserne er der anvendt farvekort, ROCK-COLOR CHART. Prøvernes placering ses pá figur 4.

G-27: Mørk gulligbrunt ( 10 YR 4/2) siltet glimmerler, med rødbrune jernudfældninger (rodspor). Den grovere fraktion bestar hovedsageligt af velpolerede kvarts korn og enkelte uidentificerede sorte partikler.

G-26: Som G-27, dog med højere grad af jernudfældninger.

G-25: Gråligbrunt (5 YR 3/2) glimmerler, en vis coating af både kvarts- og glimmerkornene.

G-24: Mørk gulligbrunt (10 YR 2/2) glimmerler. Enkelte velpolerede grønligsorte korn, sandsynligvis pellets.

G-23: Som G-24, samt svagt lamineret.

G-22: Som G-24, dog flere pellets

G-21: Som G-24, Dog et højere lerindhold og flere pellets. Brokket brudflade.

G-20: Som G-24, samt pyritiserede gravegange og fossiler.

G-19: Som G-24, spredte pyritiserede gravegange, generelt mange ellipsolde korn (pellets), visse steder $i$ ansamlinger og generelt orienteret parallelt med lagplanene. 
G-18: Som G-19.

G-17: Som G-19.

G-16: Som G-19.

G-15: Som G-24, samt molluskfragmenter og enkelte bryozofragmenter. Brokket brudflade.

G-14: Som G-24. Brokket brudflade.

G-13: Som G-24, pyritiserede gravegange, samt et højere calcit indhold. Brokket brudflade.

G-12: Som G-24, pyritiserede gravegange, samt et højere calcit indhold. Brokket brudflade.

G-11: Som G-24, pyritiserede gravegange, samt et højere calcit indhold. Brokket brudflade.

G-10: Som G-24, Gravegange af varierende tykkelse op til $1 \mathrm{~mm}$, samt et højere calcit indhold.

G-9: Som G-24, gravegange af varierende tykkelse, samt et højere calcit indhold. Brokket brudflade.

G-8: Som G-24, gravegange af varierende tykkelse, ekstrem mange pellets. Brokket brudflade.

G-7: Som $G-24$, gravegange af varierende tykkelse, ekstrem mange pellets. Brokket brudflade.

G-6: Som G-24, gravegange af varierende tykkelse, mange pellets. Brokket brudflade.

G-5: Som G-24, gravegange af varierende tykkelse, skalmateriale. Muslet brudfiade.

G-4: Som G-24, gravegange af varierende tykkelse. 
G-3: Som G-24, gravegange af varierende tykkelse. Muslet brudflade.

G-2: Som G-24, gravegange af varierende tykkelse. Muslet brudflade.

G-1: Som G-24, gravegange af varierende tykkelse, mange pellets. Brokket brudflade.

Sand fraktionen

Efter sigtning er fraktionen større end $63 \mu \mathrm{m}$ blevet undersøgt i mikroskop. Denne fraktion består hovedsageligt af pyritiserede pellets, pyritiserede gravegange, glimmer, skaller og enkelte korn af kvarts og feldspat.

En del af de pyritiserede pellets har et grønligt skær, som formodenligt stammer fra glaukonit.

Den største del af sandfraktionen er sandsynligvis dannet efter at sedimentet er aflejret, og er derfor udeladt i kornstørrelsesanalysen

Gravegange

I Gram leret fremtræder gravegangene som pyritiserede stængler. De forekommer hovedsageligt i to tykkelser. De største har en tykkelse fra $0,3 \mathrm{~mm}$ til $1 \mathrm{~mm}$ og de mindste er ca. 0,05 mm tykke. 
I den unders $\varnothing$ gte del af Gram leret er der fundet tre variationer, hvormed gravegangene optræder. Som før næunt er der forskel på tykkelsen og derudover kan de store inddeles i to forskellige typer: 1) En massiv type, hvor hele gravegangen er pyritiseret. 2) En type der har en skal af pyritiseret materiale og en kerne bestaende af pyritiserede pellets, der ofte er coatede af et sort materiale.

De tre gravegangstyper er illustreret i figur 5 .

Ud fra de 6 radiografier (Tavlerne 1 og 2) ses det, at de tykke gravegange oftest er orienterede vinkelret på lagplaner. Længden af gravegangene er svær at bestemme idet mange er brudt istykker, dog kan flere følges over ca. $15 \mathrm{~cm}$. De tynde graveganges orientering varierer mellem parallel og vinkelret pá lagplaner i forskellige niveauer. I den $\varnothing$ verste del af profilet falder antallet af gravegange, og her er det hovedsageligt de tynde, der forekommer.

Type 1: Smal massiv gravegang

Type 2: Bred massiv gravegang

Type 3: Bred gravegang med en pyritiseret skal og en kerne bestáende af pellets

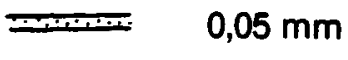

$1 \mathrm{~mm}$

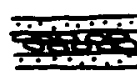
$1 \mathrm{~mm}$

Fig. 5. Skitse af de tre gravegangstyper.

Fig. 5. Sketch of the three types of burrows. 
Pellets optræder som gullige (glinsende) og sorte ellipsoide korn med et svagt grønligt skær. Kornene er op til $0,5 \mathrm{~mm}$ (b-akse) og med et længde/tykkelse forhold på ca. 2:1. I denne del af Gram leret er de pyritiserede.

Op gennem profilet varierer mængden af pellets; stedvist $i$ ansamlinger. I visse horisonter erkendes en orientering af pellets parallelt med lagplanerne.

Konkretioner

Konkretionerne i Gram leret optræder som lys gulligbrune ellipsoide legemer med uregelmassige overflader. Konkretionerne er ca. $15 \mathrm{~cm}$ lange $0 \mathrm{~g} 10 \mathrm{~cm}$ tykke. Inde i konkretionerne ses ofte aftryk af krabber omgivet af et sort, stedvist fedtet, materiale.

I profilet kan konkretionerne følges i 4 niveauer: A, B, C og $E$ (fig. 6). I et femte niveau (D) er enkelte konkretioner observeret.

I de to nederste horisonter (A og B) optræder konkretionerne hyppigst, $i \mathrm{C}$ og $\mathrm{E}$ horisonterne ligger de mere spredt, og som før næunt er der kun fundet enkelte konkretioner i D horisonten. 


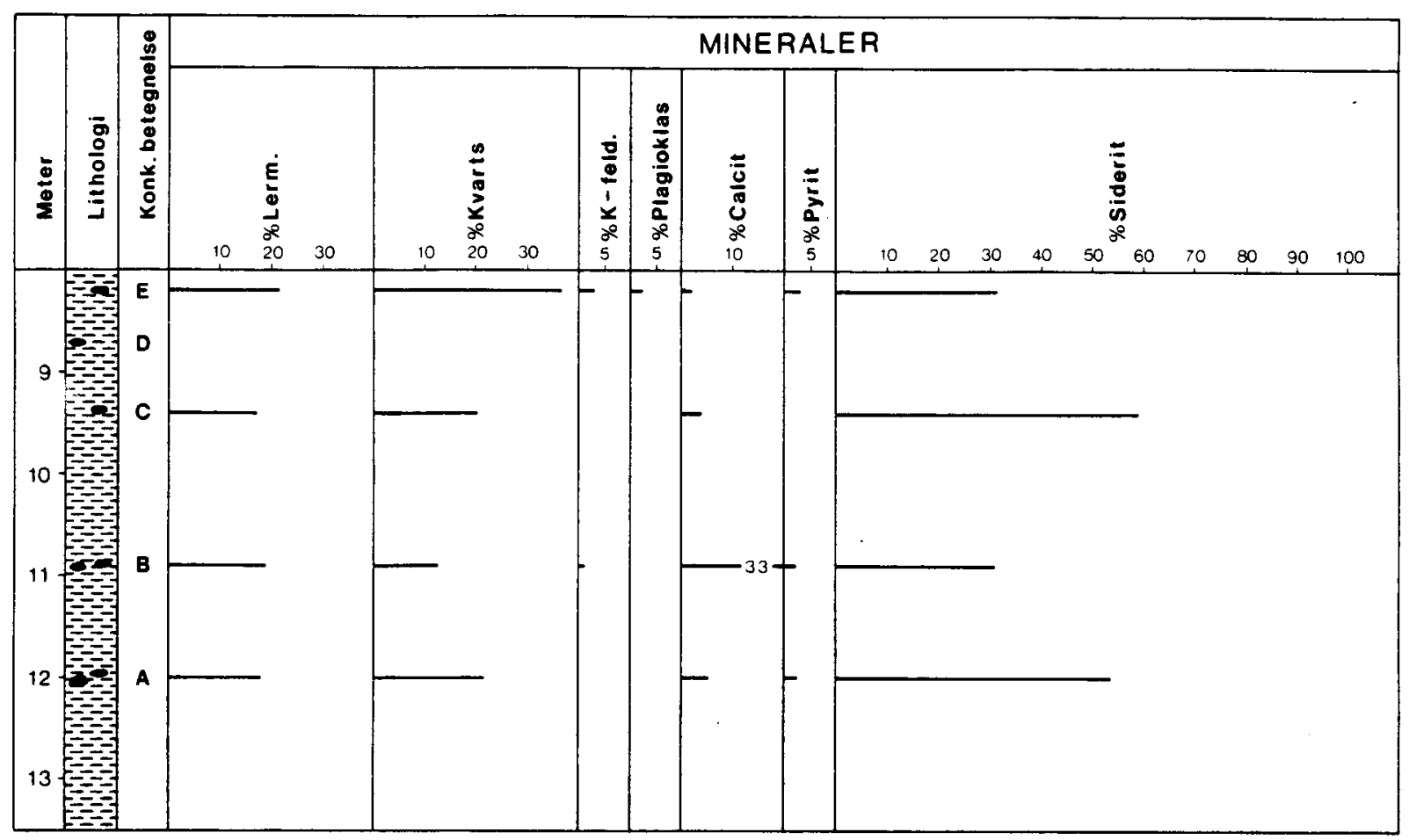

Fig. 6. Resultater fra bulkmineralogisk analyse af konkretioner.

Fig. 6. Results of bulkmineralogical analysis of concretions. 


\section{Radiografianalyse}

På tavlerne 1 og 2 er vist radiografier fra 6 niveauer i sedimentet. Radiografierne viser hovedsagligt fordelingen af pyritiserede gravegange.

De fem nederste prøver er karakteriseret ved tilstedeværelse af lange, tykke gravegange, hovedsagligt orienterede vinkelret på lagplanerne. Endvidere ses en vekslende mængde, tyndere gravegange, der er orienterede parallelt med lagplanerne. Den $\emptyset$ verste prøve indeholder kun fà, korte, tynde gravegange med tilfældige orienteringer. I denne prøve erkendes cm-store pyritiserede ansamlinger. Dette kan repræsentere ansamlinger af større gravegangsfragmenter. 
Bulkmineralogi

Følgende mineraler er identificeret: Lermineraler, kvarts, kalifeldspat, plagioklas, calcit, dolomit, pyrit og gibbsit ( $f i g \cdot 7)$.

Lermineraler: Indholdet varierer omkring $45 \%$ fra $13 \mathrm{~m}$ til $3 \mathrm{~m}$. Herover er der et generelt fald til 25\% ved toppen. Der ses dog en afvigelse ved $1,75 \mathrm{~m}$, med $40 \%$.

Kvarts: Varierer omkring $40 \%$ fra $13 \mathrm{~m}$ til $3 \mathrm{~m}$ og herover en stigning til $60 \%$ ved toppen.

Kalifeldspat: Generelt mindre end $4 \%$ og med størst afvigelse $i 9,5 \mathrm{~m}$ med et indhold pà $11 \%$.

Plagioklas: Generelt mindre end $4 \%$ og med størst afvigelse herfra i $13 \mathrm{~m}$ og $1,25 \mathrm{~m}$, hvor indholdet er hhv. $7,5 \%$ og $8,3 \%$.

Calcit: Indhold på mindre end 5\%, med svagt faldende tendens opad.

Dolomit: Findes hovedsageligt under $8 \mathrm{~m}$, med optil $1,4 \%$.

Pyrit: Fra $13 \mathrm{~m}$ til $4 \mathrm{~m}$ varierer indholdet mellem $2,5 \%$ og $4 \%$. Herover fàes en stigning til $7,5 \%$ i $2,5 \mathrm{~m}$ og et fald til $0 \%$ ved toppen. 


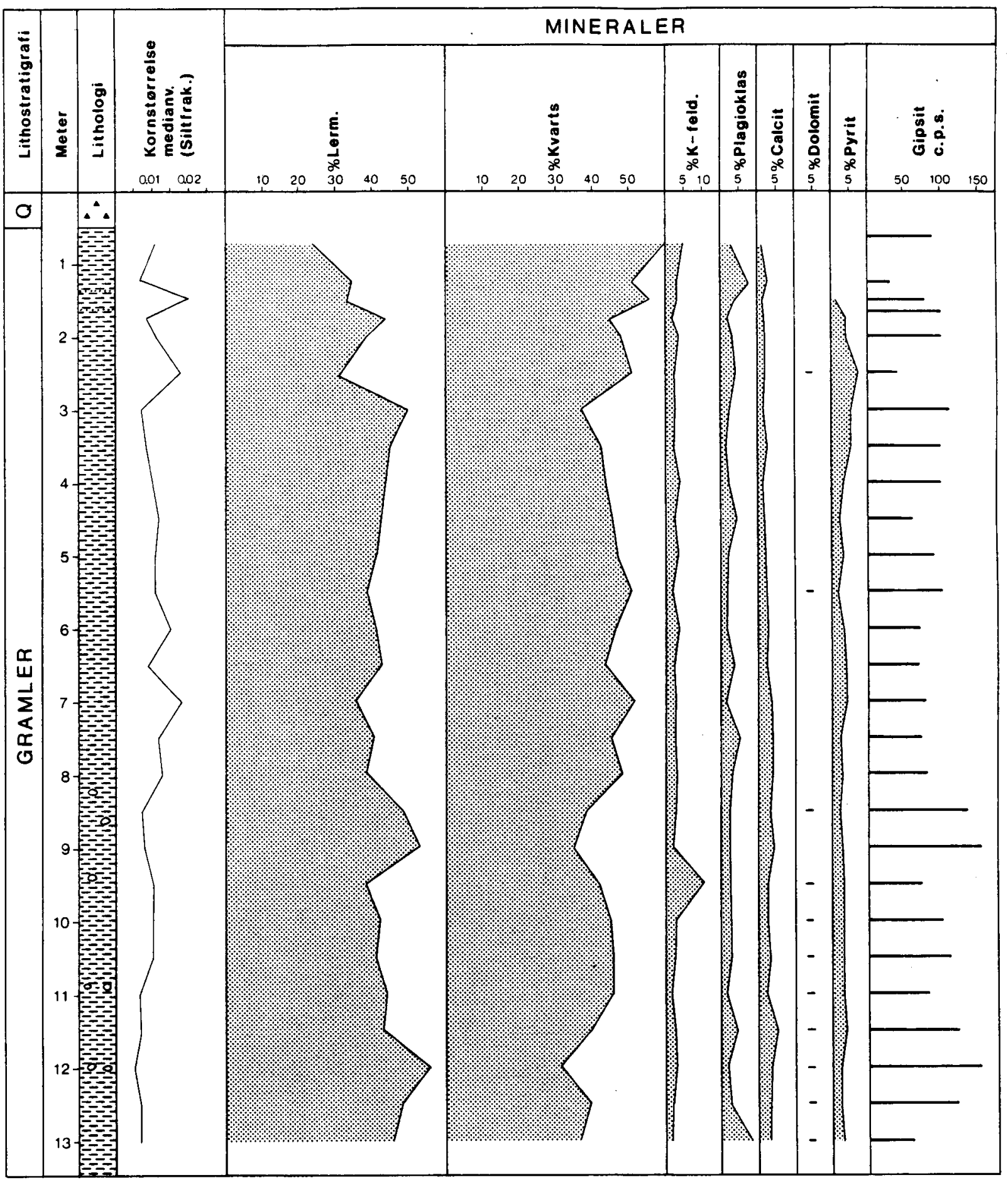

Fig. 7. Resultater af bulkmineralogisk analyse.

Fig. 7. Results of bulkmineralogical analysis. 
Gibbsit: Indholdet er ikke kvantificeret idet ingen intensitetsfaktor er tilgængelig. c.p.s. værdierne er normerede med samme faktorer som de andre mineraler. Variationen $i$ gibbsit indholdet $\varnothing \varnothing$ lger samme tendens som indholdet af lermineraler.

\section{Lermineralogi}

Følgende lermineraler er identificeret: Kaolinit, illit og smektit (fig. 8).

Kaolinit: Indholdet varierer omkring 40\% fra $13 \mathrm{~m}$ til $6 \mathrm{~m}$ og fra $5,5 \mathrm{~m}$ til $0 \mathrm{~m}$ stiger indholdet fra ca. $35 \%$ til ca. 50\% omkring siltlagene og ca. $60 \%$ i toppen

Illit: Indholdet varierer omkring $30 \%$, dog op til $40 \%$ i bunden og i toppen.

Smektit: Indholdet varierer meget omkring $20 \%$ fra $13 \mathrm{~m}$ til $1,75 \mathrm{~m}$, hvorover indholdet falder.

Geokemi

Se figur 9.

Org. C: Ret konstant indhold omkring $2 \%$. Minimumsvardi i $8,5 \mathrm{~m}(0,77 \%)$ og maximumsværdi $\mathrm{i} 3 \mathrm{~m}(2,80 \%)$ og herover faldende til $0,40 \%$ i $0,25 \mathrm{~m}$. 


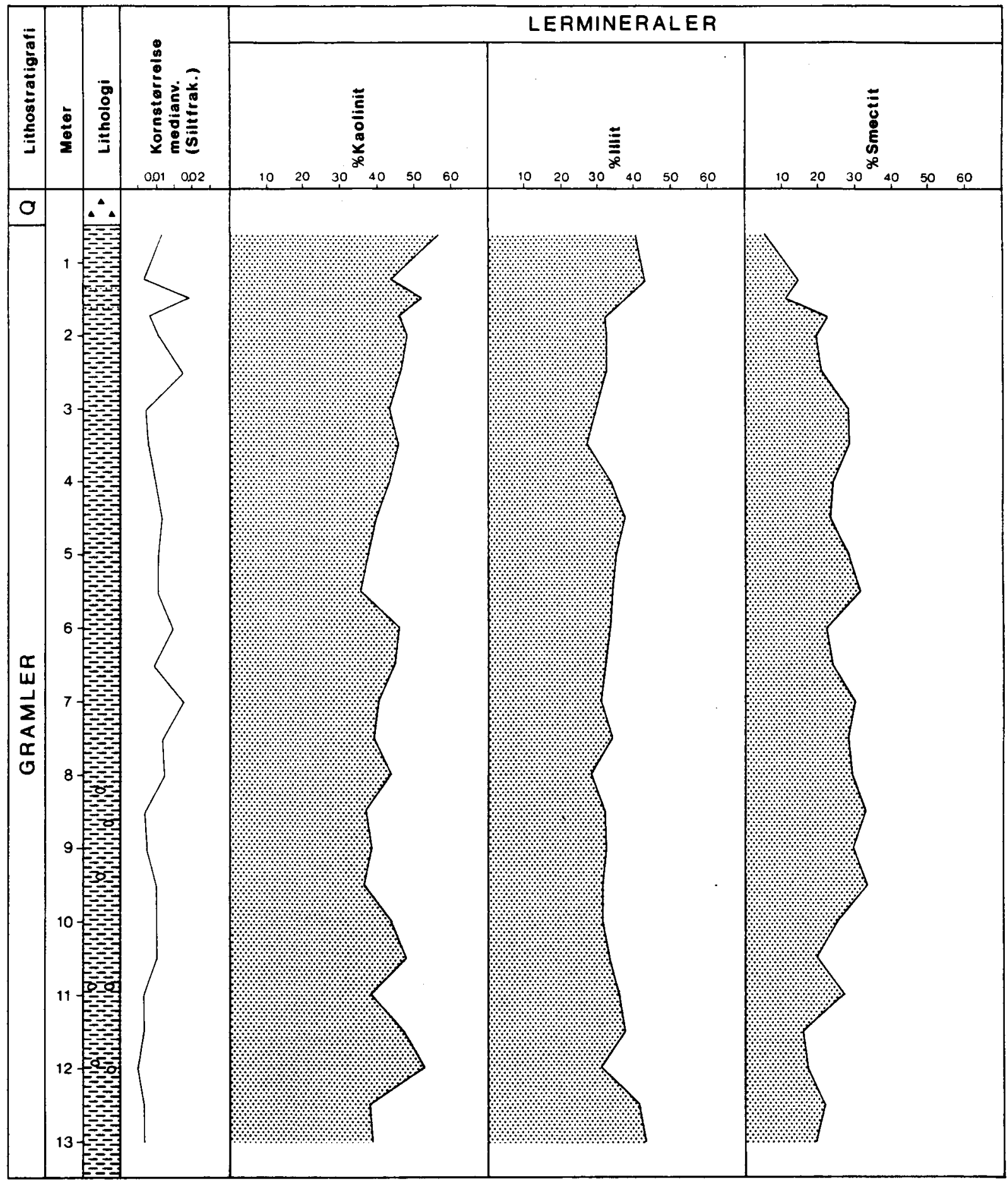

Fig. 8. Resultater af lermineralogisk analyse.

Fig. 8. Results of clay mineralogical analysis. 
$\mathrm{CaCO}_{3}$ : Alt $\mathrm{CO}_{2}$ i LECO-analysen er henregnet til $\mathrm{CaCO}_{3}$, men reelt indgår en del af $\mathrm{CO}_{2}$ i dolomit og mixed calcit. Kurveforløbet viser generelt høje vardier fra $7,5 \mathrm{~m}$ til $13 \mathrm{~m}$ på op til ca. $7 \%$, og herover er indholdet varierende mellem $0 \%$ og $2 \%$.

CaO: $\mathrm{H} \varnothing$ je værdier i $7,5 \mathrm{~m}$ og $13 \mathrm{~m}$ på henholdsvis $1,92 \%$ og $2,1 \%$. Resten indeholder ca. $1 \%$ med faldende tendens opefter.

Mg0: Ret konstant mellem $1,5 \%$ og $2 \%$.

MnO: Ret konstant ca. 0,03\%.

$\mathrm{K}_{2} \mathrm{O}:$ Ret konstant ca. $2,5 \%$.

Fe: Typisk lidt over $6 \%$, men $i$ niveauet omkring konkretioner lidt lavere.

$\mathrm{Na}_{2} \mathrm{O}$ : Ret konstant ca. $0,4 \%$

$\mathrm{Al}_{2} \mathrm{O}_{3}$ : Mellem $15 \%$ og $17 \%$, dog med en markant afvigelse i $\mathrm{G} 3$ og G9 med hhv. 22,79\% og $20,34 \%$.

S: Fra $13 \mathrm{~m}$ til $4 \mathrm{~m}$ varierer indholdet omkring $1,5 \%$. Herover stiger indholdet til $4 \%$ i $2,5 \mathrm{~m}$ og falder igen mod toppen til $0,026 \%$.

\section{Bulkmineralogi af finsandslagene}

Mineralogien er her karakteriseret ved lavere lerindhold (ca. 30\%) og højere kvartsindhold (ca. 58\%) end det underliggende sediment. Pyritindholdet er lavt (ca. 1,5\%) (tabel A i Appendix 2, prøve GLS-1 og 2). 


\section{Bulkmineralogi af konkretionerne}

Fळlgende mineraler er identificeret: Lermineraler, kvarts, kalifeldspat, plagioklas, calcit, pyrit og siderit (fig, 6).

Karbonatandelen udgør ca. $60 \%$, dog ca. $30 \%$ i B. Siderit dominerer $i \mathrm{~A}, \mathrm{C}$, og $\mathrm{E}$, mens $\mathrm{B}$ består af lige dele siderit og calcit. Lermineralindholdet ligger på ca. 20\%. Kvartsindholdet er mere svingende, $15 \%$ til 35\%. Kalifeldspat erkendes $i \quad B$ og $E$. Plagioklas kun $i$. Pyrit udgør ca. $2 \%$ af konkretionerne, dog er det ikke tilstede i $C$.

\section{Kornst $\varnothing r r e l s e s a n a l y s e$}

Middelkornstørrelsen (medianen) ligger generelt indenfor mellemkornet silt (fig. 10). Værdierne er noget varierende, men viser en svag stigning opad i profilet. 


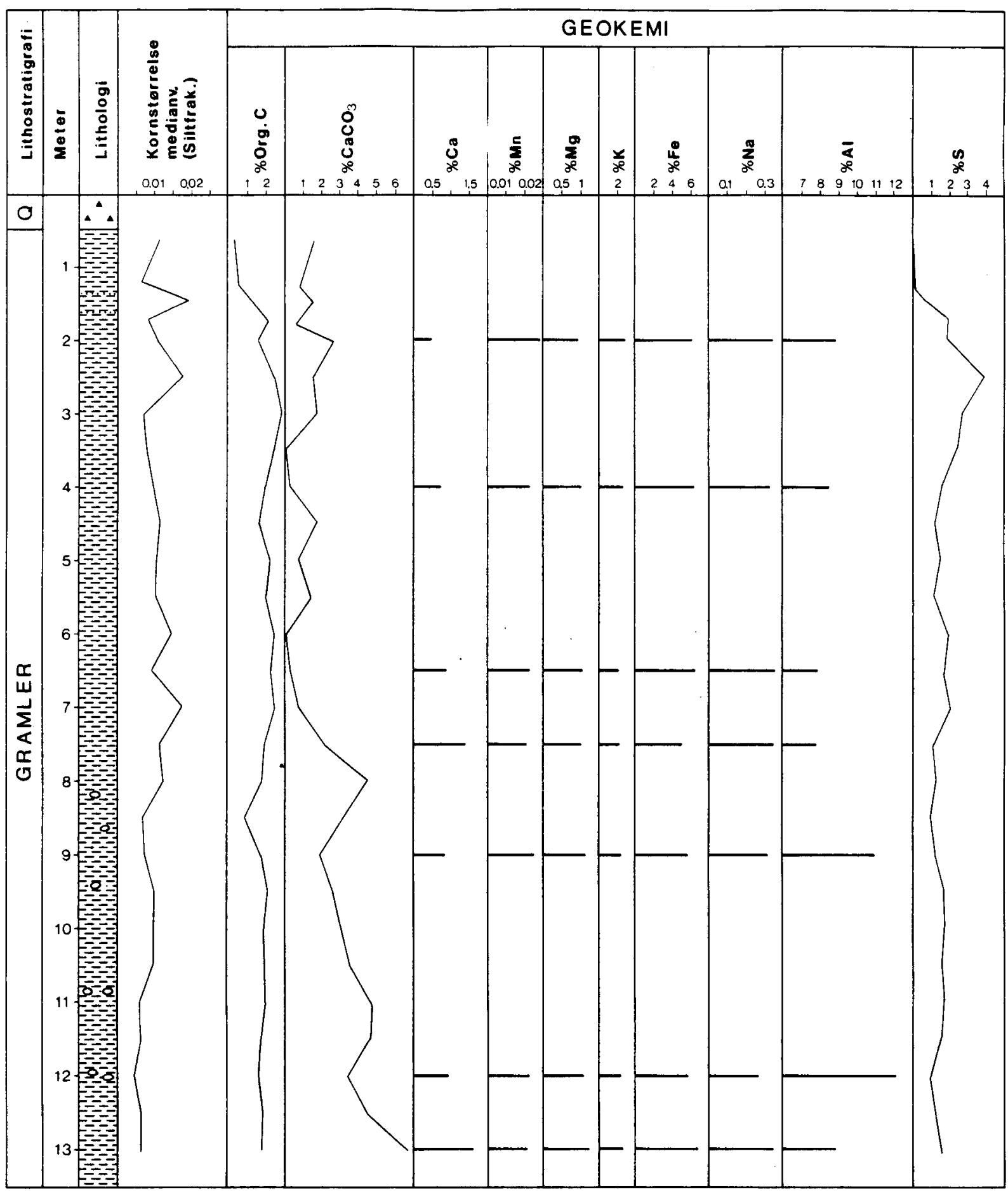

Fig. 9. Resultater fra geokemiske analyser.

Fig. 9. Results of geochemical analysis. 


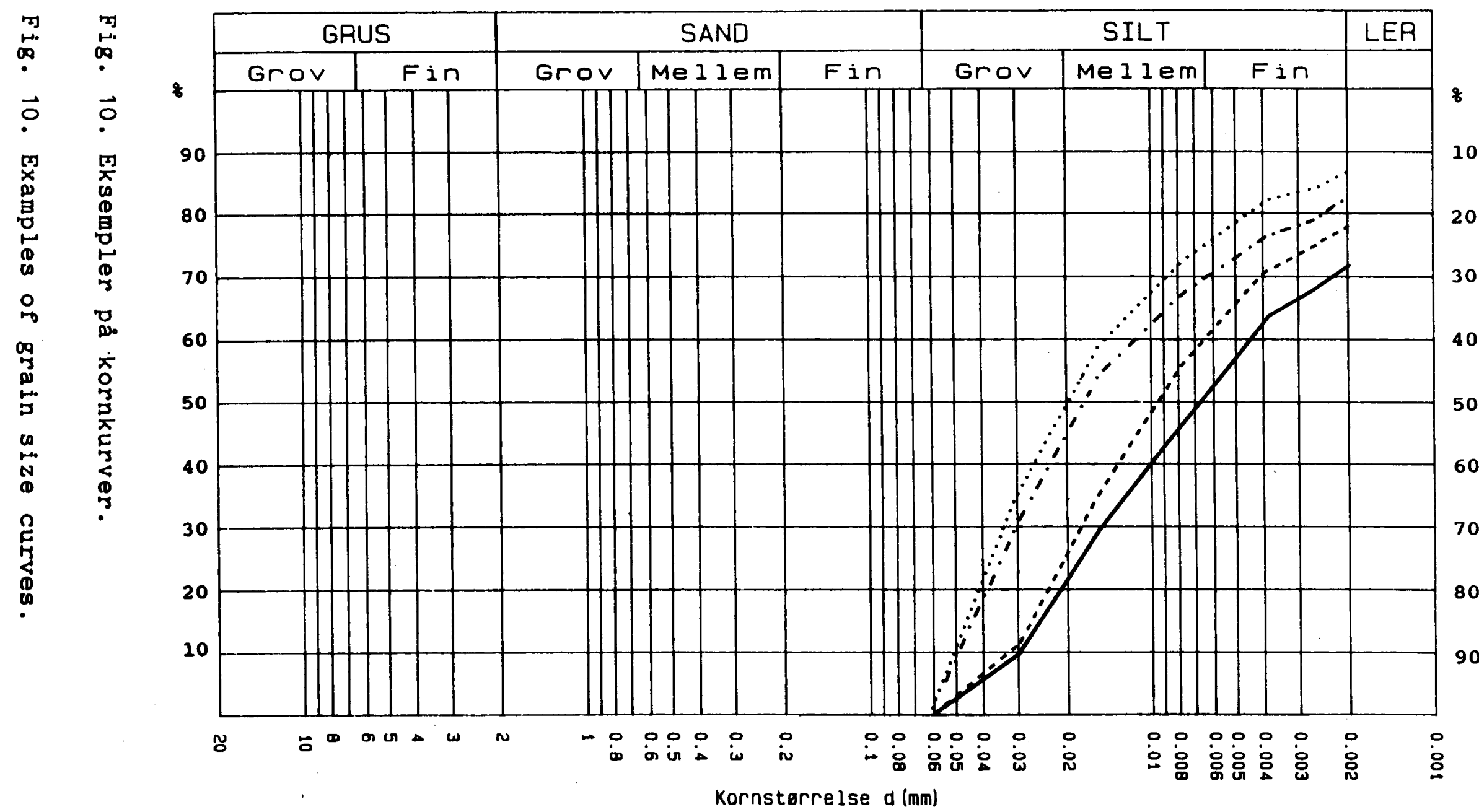

Kornstørrelse d (mm) 
For mineraler med forholdsvis rene sammensatninger, kan sammenhængen vurderes ved plot af kemiske data mod mineralogiske data.

Fordelingen af punkter $i$ en sådan diagramtype sammenlignes med en teoretisk linie, der reprasenterer fordelingen af punkter under forudsætning af, at det analyserede element kun findes $i$ det pågældende mineral og, at mineralet har støkiometrisk sammensætning.

I tilfælde med lermineraler, glimmer og feldspater bliver usikkerhederne i denne type diagrammer store, p.g.a. mineralernes brede kemiske sammensatningsspektre.

Ca: Ca findes hovedsagligt i karbonater, det vil her sige calcit, mixed calcit og dolomit, $\circ g$ i mindre grad $i$ feldspat.

Indholdet af calcit er malt ved $X R D$ og indholdet af $\mathrm{CO}_{2}$ ved Leco analyser.

I figur 11 er det totale karbonatindhold fra XRD analyse plottet mod karbonatindhold fra Leco analyse, hvor det for sidstnævnte indhold er antaget, at alt $\mathrm{CO}_{2}$ findes i calcit. De enkelte punkter afviger en del fra den teoretiske linie.

Punkter under den teoretiske linie kan stamme fra prøver med et indhold af aragonit, der ikke er medregnet i XRD analysen.

I figur 12 er calcitindholdet fra XRD analyse plottet 


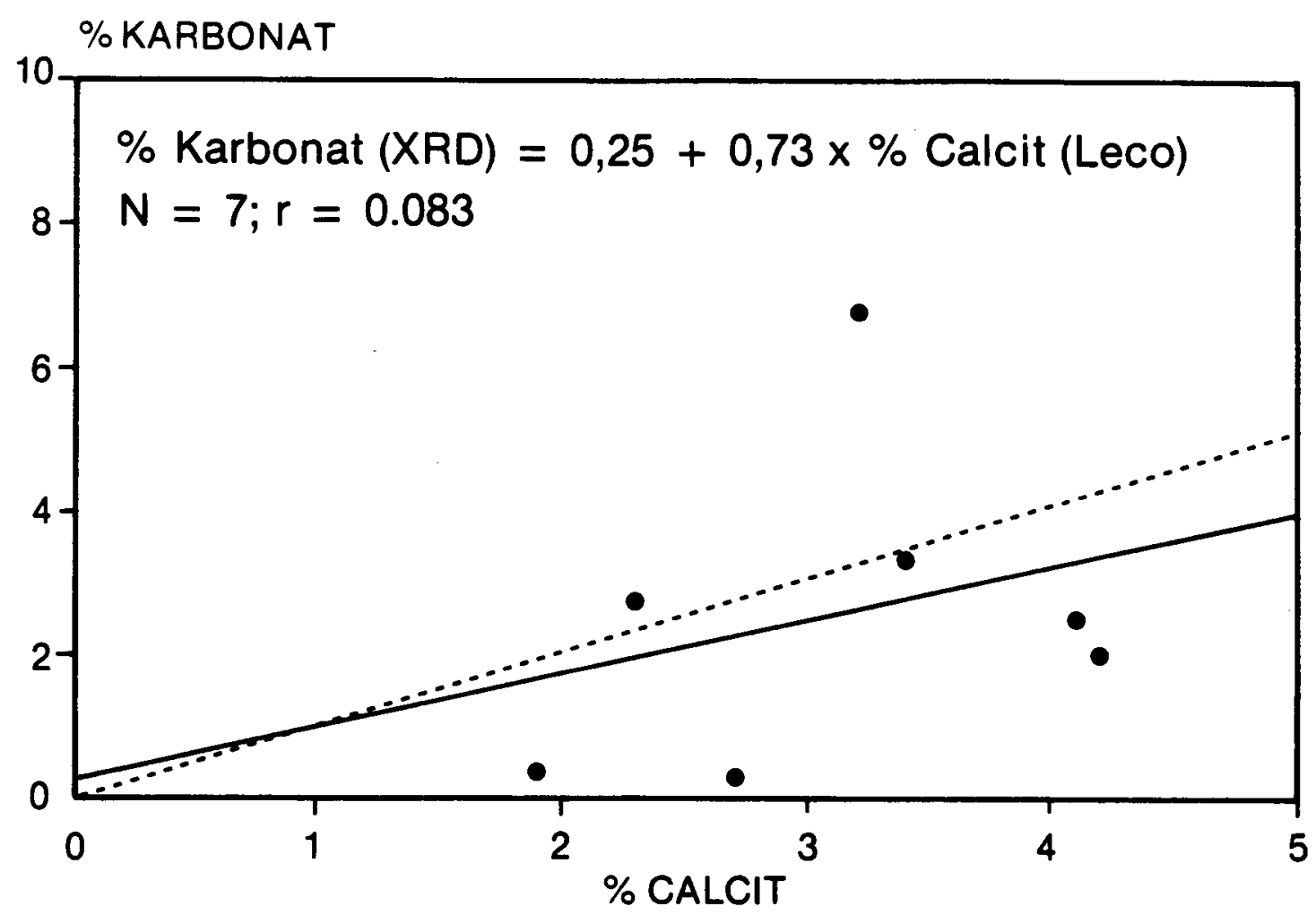

Fig. 11. Plot af det totale indhold af karbonatmineraler fra XRD-analyse mod beregnet calcitindhold fra Leco-analyse. Stiplet linie representerer teoretisk fordeling, hvis calcit er eneste karbonatmineral. Den fuldt optrukne linie er den beregnede regressionslinie.

Fig. 11. Plot of total carbonate minerals (XRD) vs. calcite (Leco). Stippled line represents theoretical distribution, assuming that calcite is the only carbonate mineral present. Solid line is calculated line of regression. 


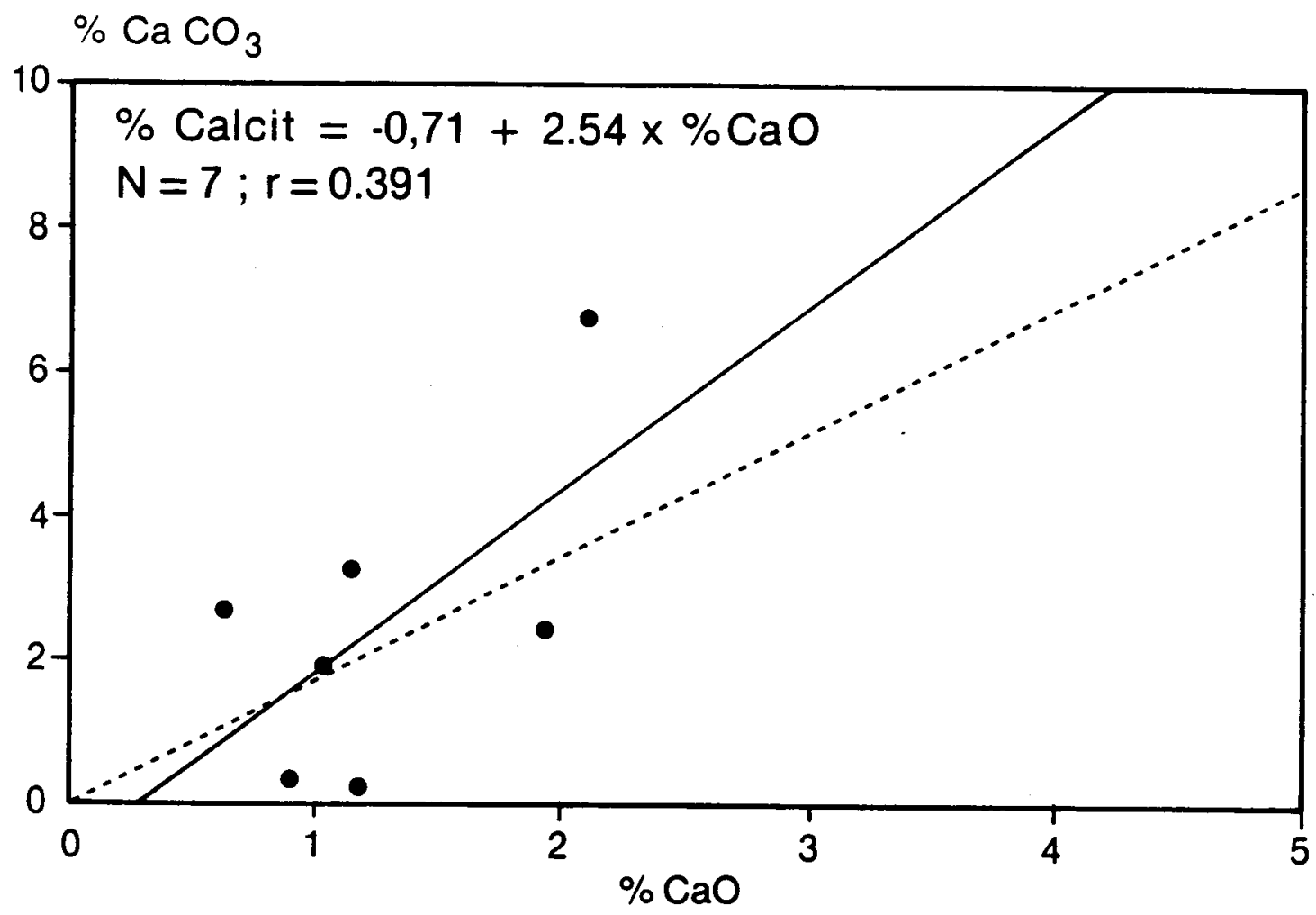

Fig. 12. Plot af calcitindholdet fra XRD-analyse mod CaOindholdet fra kemianalysen. Stiplet linie repræsenterer teoretisk fordeling, hvis $\mathrm{CaO}$ udelukkende findes i calcit. Den fuldt optrukne linie er den beregnede regressionslinie.

Fig. 12. Plot of calcite (XRD) vs. CaO (chemistry). Stippled line represents theoretical distribution assuming that CaO only is present in calcite. Solid line is calculated line of regression. 
mod CaO indholdet fra kemi analysen. Her ses ligeledes en nogenlunde gennemsnitlig overensstemmelse med den teoretiske linie, men enkelte analyser afviger noget fra linien. Afvigelsen er dog mindre end pả figur 11.

De fleste analyser viser nogenlunde overensstemmelse mellem kemiske og mineralogiske data, og de fleste afvigelser kan forklares ved tilstedeværelse af flere typer karbonatmineraler, hvilket også erkendes ved XRD analyser.

Mn: Mn findes hovedsagligt i karbonater og i mindre grad i lermineraler.

Udenfor konkretionerne er Mn indholdet lavt og meget konstant, medens det i konkretionerne er 10-20 gange højere. Dette kan skyldes tilstedeværelse af $\mathrm{Mn} i$ siderit og/eller, at MnO er tilstede 1 det sorte fedtede materiale, der ses som belægning på krabberne 1 konkretionerne.

Mg: $\quad M g$ findes $i$ mixed calcit, dolomit, lermineraler og glimmer.

$\mathrm{Mg}$ indholdet er meget konstant udenfor konkretionerne, men er 2-3 gange højere $i$ konkretionerne. Dette kan skyldes Mg-substitutioner i calcit og siderit, der optræder med storre hyppighed 1 konkretionerne.

$K: \quad K$ findes $i$ illit, $K$-feldspat og glimmer og $i$ mindre grad $i$ smektit og kaolinit. $K$ indholdet er meget konstant $i$ sedimentet, men or ca. 2 gange sá høj i enkelte konkretioner.

Fe: Analyserne viser ikke relative mangder af oxideret og reduceret jern men det totale jernindhold.

I sedimentet findes jern hovedsagligt $i$ pyrit og $i$ mindre grad i lermineraler, glimmer og evt. i karbonater. I konkretioner findes jern hovedsagligt i siderit. 
I figur 13 er pyritindholdet fra XRD analysen plottet mod total indhold af jern i sedimentet.

Det ses heraf, at punkterne fordeles omkring en linie med samme hældning som den teoretisk beregnede linie, men med gennemsnitlig 4\% overskydende jern. Dette forhold kan skyldes, at intensitetsfaktoren for pyrit er for høj, dvs. at det reelle pyritindhold er højere end det beregnede. Denne mulighed er formodentlig ikke særlig betydende, idet analyser af svoviindhold ikke indikerer højere pyritindhold end det beregnede (se svovl-analyser). En mere sandsynlig mulighed er derfor, at der findes et relativt konstant jernindhold pá ca. $4 \%$ i andre mineraler, formodentlig i lermineraler, glimmer og máske i karbonater. Jerns tilstedeværelse i lermineraler sandsynliggøres af, at lerfraktionen indeholder ca. 5\% Fe (Tabel C i Appendix 2).

I figur 14 er sideritindholdet fra XRD analysen plottet mod det totale Fe indhold fra kemianalysen.

Det ses heraf, at næsten alt $F e$ i konkretioner er bundet i siderit. En mindre del Fe findes i pyrit.

$\mathrm{Na}$ : Na findes i smektit, feldspat, glimmer og i lille grad i illit og kaolinit.

Indholdet af $\mathrm{Na}$ er meget konstant i sedimentet. Konkretioner indeholder generelt mindre $\mathrm{Na}$, hvilket formodentlig reflekterer det lavere indhold af lermineraler, glimmer og feldspat heri. 
$\%$ PYRIT

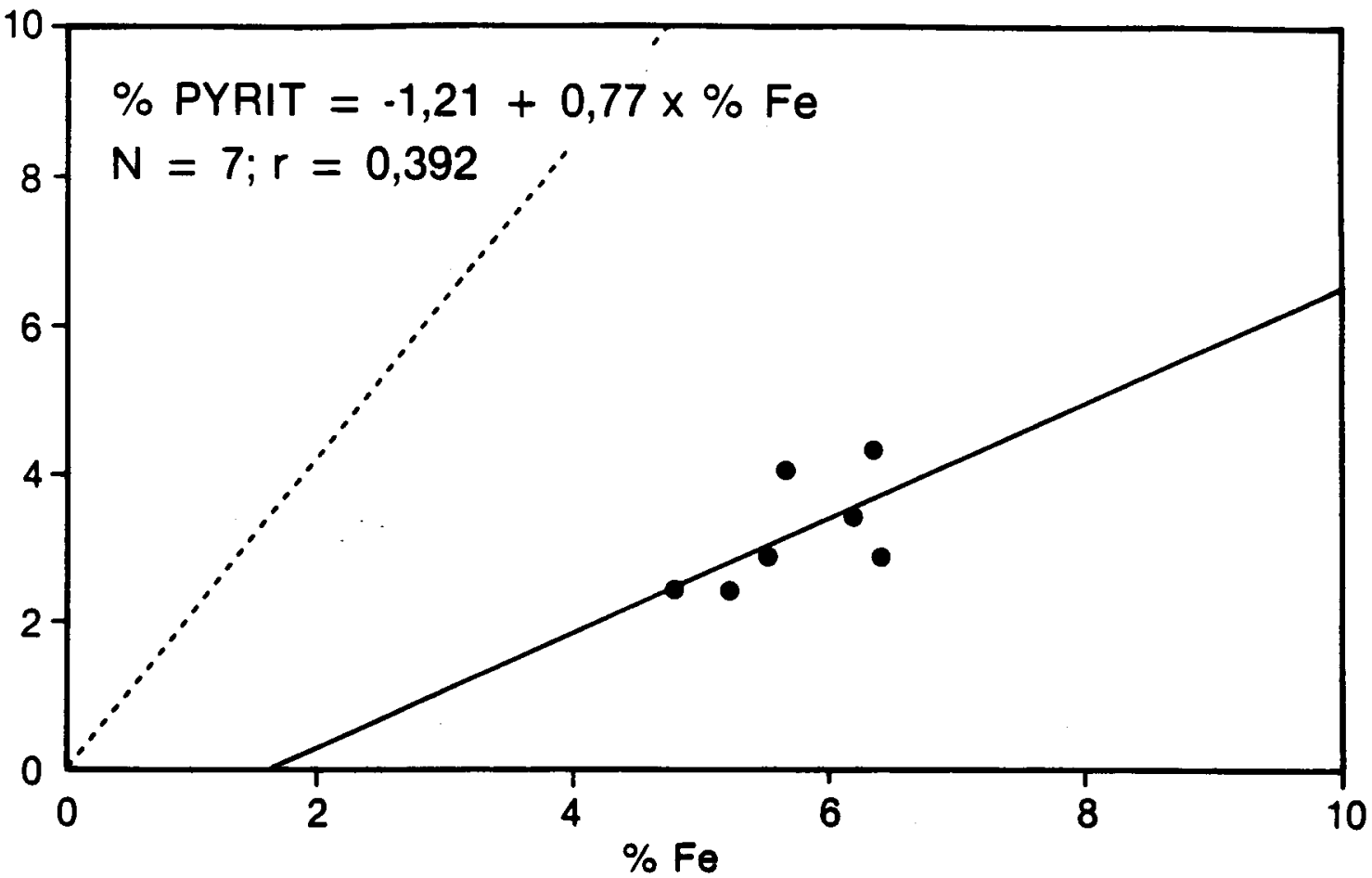

Fig. 13. Plot af pyritindholdet fra XRD-analysen mod det totale jernindhold fra kemianalysen. Stiplet linie repræsenterer teoretisk fordeling, hvis jern kun er tilstede i pyrit. Den fuldt optrukne linie er den beregnede regressionslinie.

Fig. 13. Plot of pyrite (XRD) vs. total iron (chemistry. Stippled line represents theoretical distribution, assuming that pyrite contain all iron present. Solid line is calculated ine of regression. 
$\%$ SIDERIT

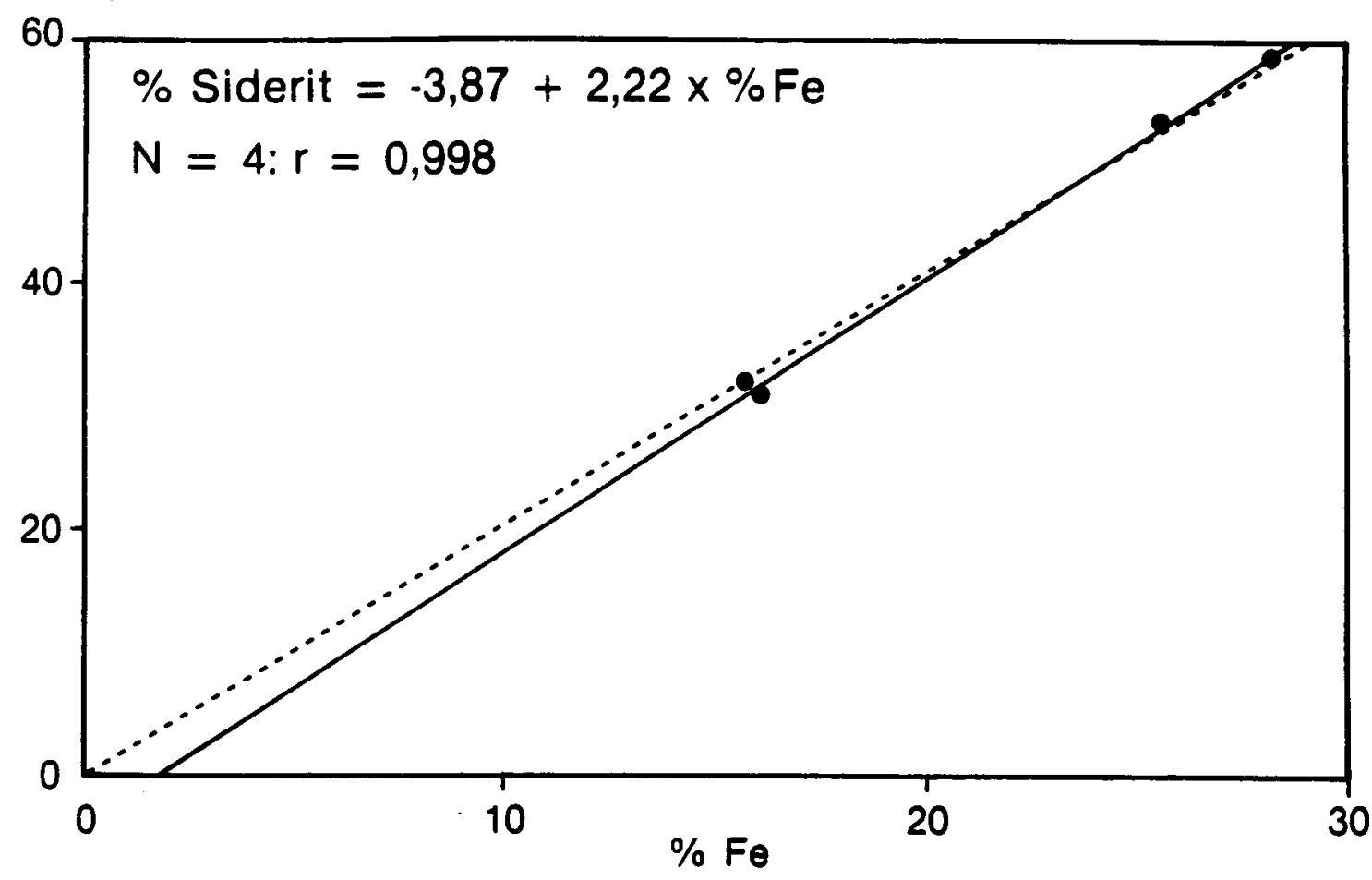

Fig. 14. Plot af sideritindhold (XRD) i konkretioner mod det totale jernindhold (kemi). Stiplet linie repræsenterer teoretisk fordeling, hvis jern kun er tilstede i siderit. Den fuldt optrukne linie er den beregnede regressionslinie.

Fig. 14. Plot of siderite (XRD) vs. total iron (chemistry) in concretions. Stippled line represents theoretical distribution, assuming that siderite contain all iron present. Solid line is calculated line of regression. 
Al: Al findes $i$ lermineraler, glimmer og feldspat.

I figur 15 er den totale mengde lermineraler fra XRD analyse plottet mod indhold af Al fra kemianalysen.

Diagrammet viser positiv korrelation med smá afvigelser, hvilket er $i$ overensstemmelse med, at den største mængde Al er bundet i lermineraler.

S: S findes i pyrit.

figur 16 er pyritindholdet fra XRD analysen plottet mod mængden af $S$ fra Leco analysen.

Punkterne fordeler sig tæt omkring den teoretisk beregnede linie, hvilket indikerer, at alt $S$ er bundet 1 pyrit og at den beregnede mængde pyrit er meget tat pá den reelle.

Tilstedeværelse af $S$ i jernmonosulfider, som organisk svovi og som elementar svovl er formodentlig ubetydelig, idet tilsetning af saltsyre ikke gav nogen erkendelig lugt. Jernmonosulfider og elementar svovl vil ved denne behanding danne $\mathrm{H}_{2} \mathrm{~S}$, som lugter kraftigt. 
$\%$ LERMINERALER

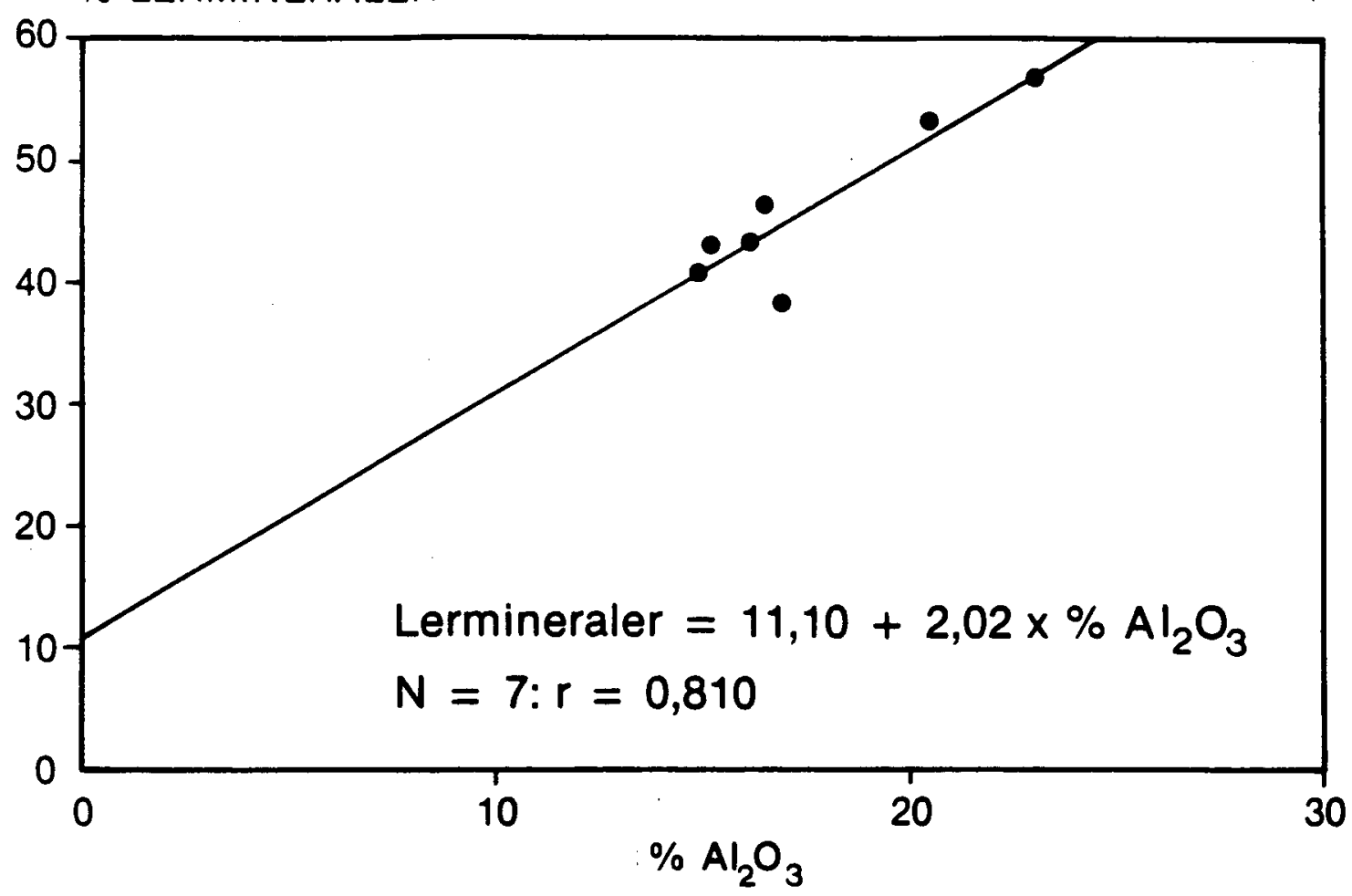

Fig. 15. Plot af totale mængde lermineraler fra XRD-analysen mod indhold af $\mathrm{Al}_{2} \mathrm{O}_{3}$ fra kemianalysen. Den fuldt optrukne linie er den beregnede regressionslinie.

Fig. 15. Plot of total amount of clay minerals (XRD) vs. amount of $\mathrm{Al}_{2} \mathrm{O}_{3}$ (chemistry). Solid Iine is calculated line of regression. 


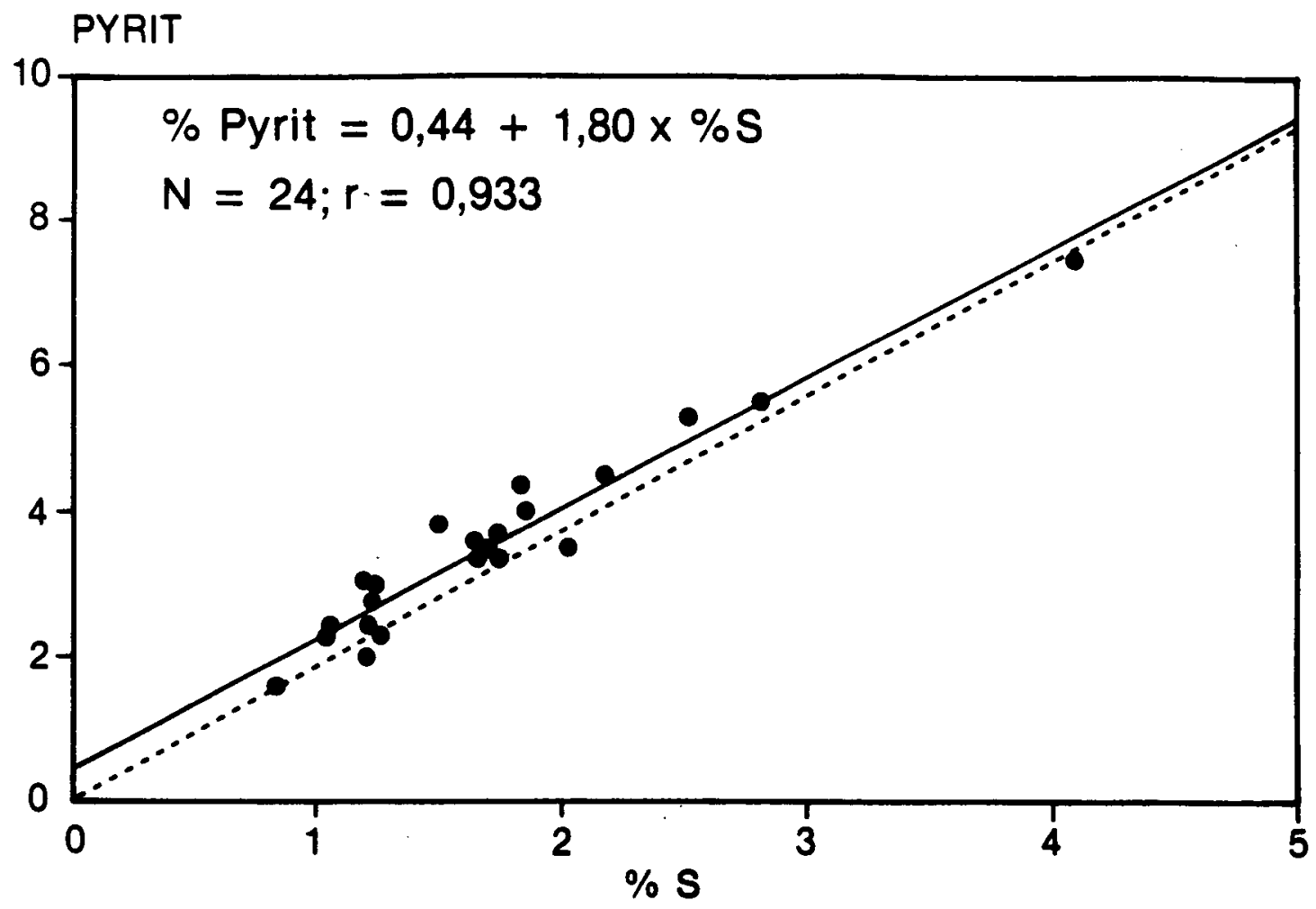

Fig. 16. Plot af pyritindholdet fra XRD-analyse mod indhold af svovi fra Leco-analysen. Stiplet linie repræsenterer fordeling, hvis svovl kun findes i pyrit. Den fuldt optrukne linie er den beregnede regressionslinie.

Fig. 16. Plot of pyrite (XRD) vs. amount of sulphur (chemistry). Stippled ine represents theoretical distribution, assuming that pyrite contains all sulphur present. Solid line is calculated line of regression. 
I det f $\varnothing$ lgende diskuteres Gram lerets aflejrings- og diageneseforløb. I diskussionen inddrages forskellige ratioværdier, der afspejler kornstørrelses-, modenheds- og mineralvariationer.

Som et mål for variation af kornstørrelsen anvendes forholdet kvarts + feldspat/lermineraler, ud fra den betragtning at grovere materialer er beriget med kvarts og feldspat $i$ forhold til finere materialer (Dypvik 1984). Endvidere undgàes authigene mineraler, der kan være en væsentlig fejlkilde, nár kornstørrelsesanalysen anvendes til tolkning af aflejringsmiljøet.

Den petrologiske modenhed af sedimentet máles dels udfra kvarts/feldspat-forholdet, der $i$ høj grad er afhængig af kildeomrádet og dels udfra $M=$ $\left(\mathrm{K}_{2} \mathrm{O}+\mathrm{Al}_{2} \mathrm{O}_{3} / \mathrm{Na}_{2} \mathrm{O}+\mathrm{MgO}\right)$ ratioen. $\mathrm{M}$ er en kemisk modenhedsparameter, der kan afspejle kildeomrádet, men for marine sedimenter kan den ogsá afhmnge af miljøet d.v.s. salinitet $o g$ aflejringsraten. Voksende vardier afspejler stigende modenhed (Bjørlykke 1974; Dypvik 1984).

Variationer 1 lermineral fordelingen vises ved lerratioer; kaolinit/smektit og kaolinit/illit. 


\section{Kildeområde}

Af detritale mineraler er der i Gram leret fundet kvarts, lermineraler, feldspater og gibbsit (fig. 7). Lermineralselskabet består af kaolinit, illit og smektit (fig. $8)$.

Tilstedeværelsen af kaolinit, op til 50\%, og gibbsit antyder at klimaet har været varmt og fugtigt, og med en intens forvitring i denudationsomradet. Undersøgelser af klimaet i tertiæret ( $f i g$. 17) bekræfter ikke denne antagelse. Fra en varm periode i Paleocæn og Eocæn falder temperaturen kraftigt i 0ligocmn, herefter stiger den langsomt og kulminerer 1 Mellem Miocæn, og under aflejringen af Gram leret er klimaet igen blevet forholdsvis køligt ( $\mathrm{fig}$. 17). En undersøgelse af floraen i tyske tertiære brunkulsforkomster, viser den samme tendens (Krutsch \& Majewski 1967). Undersøgelser af oligocæne og miocane sedimenter viser at gibbsit optræder fra og med Øvre Oligocæn (Nielsen 1983; Andreasen 1985; Rasmussen 1987; Beyer 1987). Det má derfor være sandsynligt, at det forholdsvis hoje kaolinitindhold og tilstedeværelsen af gibbsit i oligocæne og miocæne sedimenter stammer fra aldre tertimre forvitringsprodukter, evt. for Gram lerets vedkommende, mellem miocæne sedimeter. Gibbsit indholdet antyder endvidere en kort transport, for dele af materialet, i fluviatilt miljo (Velde 1985).

Undersøgelser af tungmineralselskaber foretaget af $G$. Larsen (Larsen \& Dinesen, 1959) tyder pá, at kildeområder 1 høj grad er det skandinaviske omráde. Tilførslen er foregáet via den nuværende Østersø (Koch et al., 1973). 


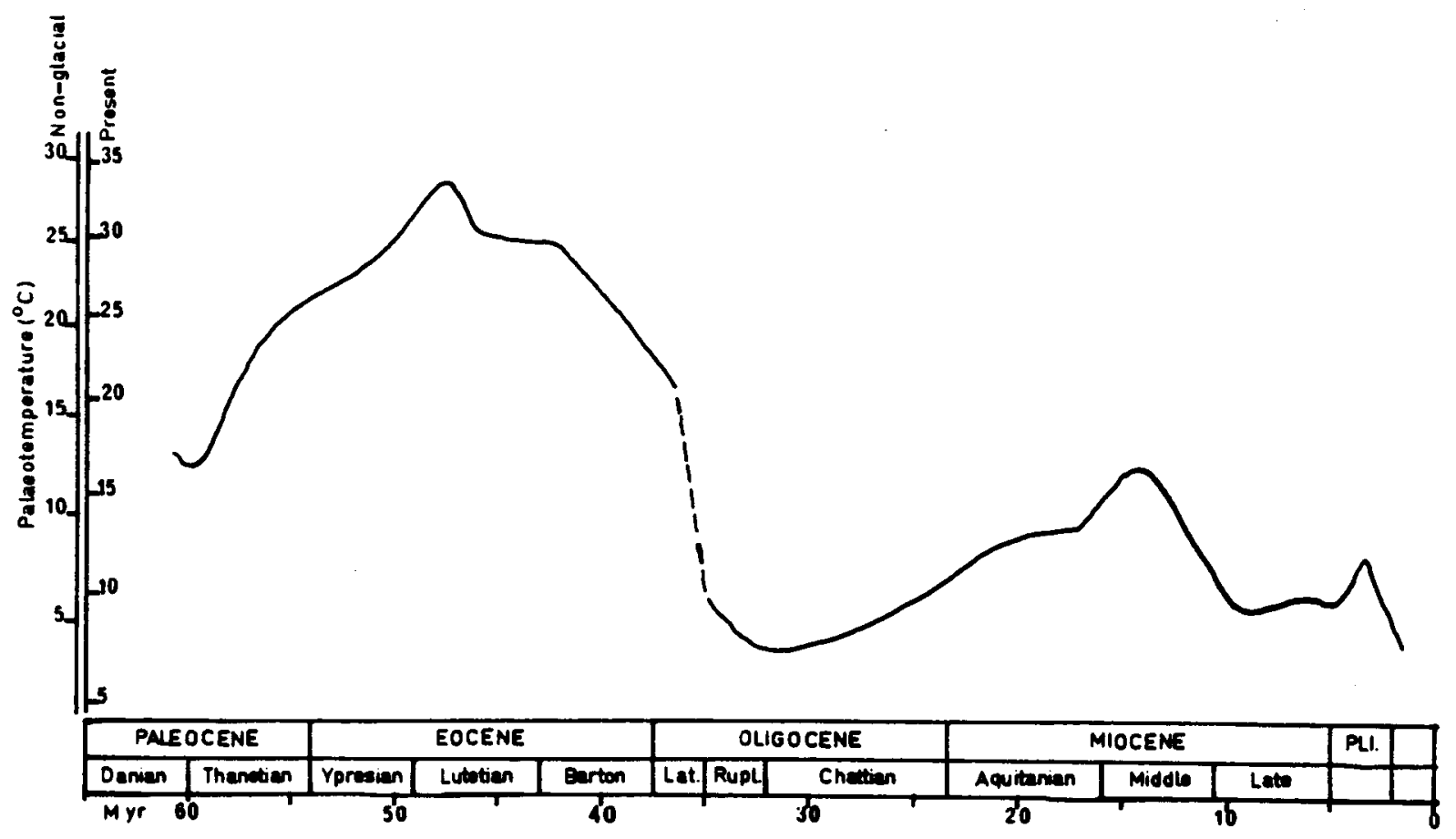

Fig. 17. Palæotemperaturen gennem Tertiær i NV-Europa. (efter Buchardt 1978).

Fig. 17. Paleotemperature through the Tertiary in NW-Europe. (after Buchardt 1978). 


\section{Aflejringsmiljø}

Sedimentet bestár af bioturberet, siltet glimmerler. $\emptyset$ verst er der erkendt to laminerede sand/siltlag, Sadanne lag er bla. beskrevet af Reineck og Singh (1980, side 395-397) og Pedersen (1985) og repræsenterer stormlag. Stormlag dannes ved at materialer transporteres med en bundstrøm fra mere kystnære områder til aflejringssteder fjernere fra kysten. Det er sandsynligt at det meste af materialerne i Gram leret er aflejret pa denne made, $O g$ at materialet senere er homogeniseret ved bioturbation. De to stormlag $\emptyset$ verst $i$ profilet er omformet af oscillerende vandbevægelser, dannet ved bølgebevægelserne. I rolige perioder er der aflejret finkornede sedimenter, bla. lermineraler. I den recente Nordsø har de kystnme stormlag en tykkelse pá over $2 \mathrm{~cm}$ og længere ude, ca. $30 \mathrm{~km}$ fra kysten, er de mindre end $1 \mathrm{~cm}$. Maximums dybden, i hvilken de findes, er op til ca. $40 \mathrm{~m}$. I den nye grav ( $f i g .1$ ) ses overst hyppige indslag af stormlag. Over graven i den vestlige ende, nær kvartær grænsen, er der blottet finsandede strukturløse sedimenter, der veksellejrer laminerede stormlag med bølgeslagsmærker. Over stormlagene erkendes tynde lerbånd (fig. 18). 


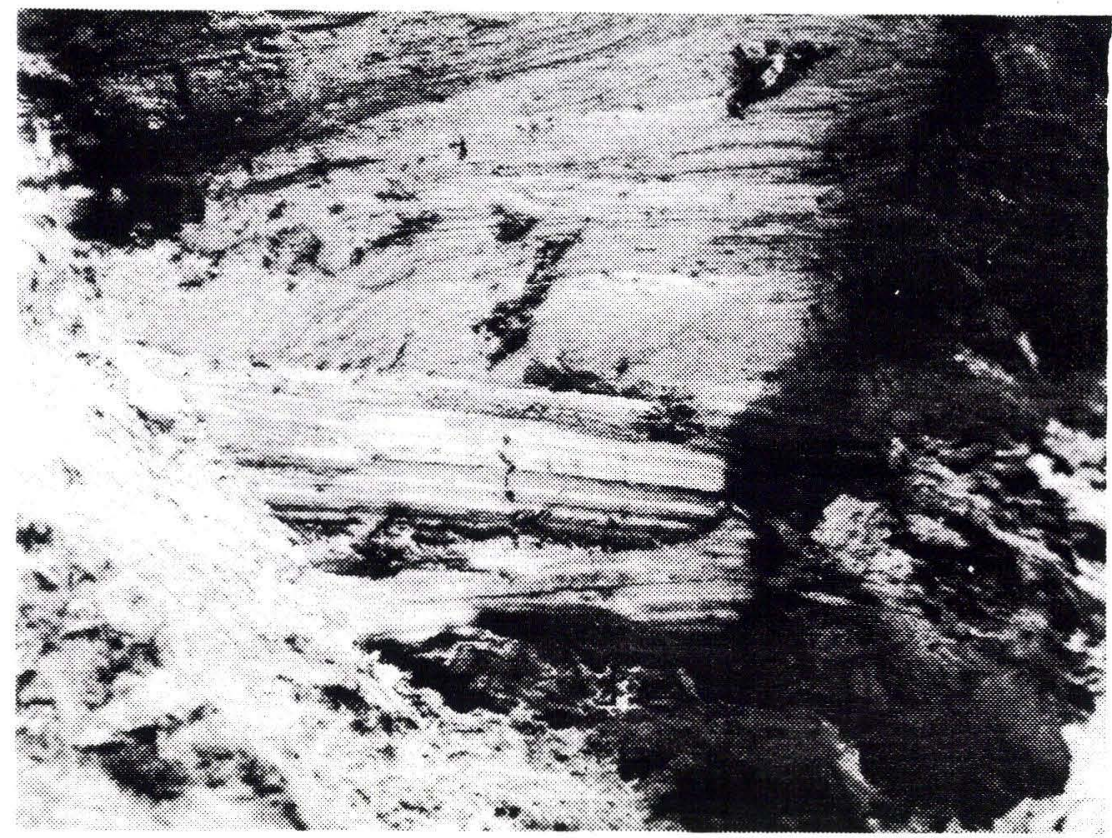

$2 \mathrm{~cm}$

Fig. 18. I bunden af billedet ses et lamineret finsands lag fra Gram leret. Øverst mod højre ses en pyritiseret gravegang. Den slyngende struktur er skrabemærker fra frilægningen af profilet. Billedet er fra den nye grav (foto $M$. Abrahamsen, Midtsønderjyllands museum, Gram).

Fig. 18. At the bottom of the picture a laminated fine sand layer is seen. Notice the pyritized burrow in the top right of the picture. The winding structure is due to the scraping to expose the profile. The picture is from the new pit. 
Radiografianalysen indikerer ligeledes, at der under aflejring af den nederste del af sedimentet har eksisteret mere rolige og ensartede forhold. Under aflejring af det $\varnothing$ verste sediment har der ikke været mulighed for opretholdelse af en stabil benthonisk fauna hvilket formodentlig repræsenterer forhold med hyppigere påvirkninger af stormbølger, der omlejrer materialerne.

Kornstørrelses parameteren $Q+F / L$ (fig. 19) korrelerer positivt med middelkornstørrelsen. Hele profilet afspejler generelt en grovende opad sekvens, hvor kvarts-og feldspatkorn er dominerende i den grovere fraktion.

Den mineralogiske modenhed, $Q / F$, er generelt under 10, med enkelte afvigelser, men der erkendes dog ingen systematisk variation. Dette svarer til modenheden $i$ andre miocæne bjergarter (Larsen og Dinesen 1959; Radwanski et al. 1975).

Modenheds parameteren, $M$, viser højere værdier $i$ de mere finkornede horisonter nederst i profilet og afspejler variationer i Al-indholdet, der er knyttet til lermineralerne. Derimod erkendes der ingen variation i indholdet af de andre oxider, som indgår i parameteren. Dette skyldes sandsynligvis at kaolinit og/eller gibbsit udgør en større andel af lerfraktionen (prøve G3 og G9), og derfor bevirker at sedimentet lermineralogisk og kemisk må anses som værende mere modent her og, at der ikke i væsentligt grad har fundet halmyrolytiske processer sted.

Lerratioerne, kaolinit/smektit og kaolinit/illit, har et nogenlunde konstant forløb med enkelte afvigelser i den nedre del af sekvensen, uden relation til kornstørrelsen. $\emptyset$ verst i profilet erkendes en generel stigning for begge parametre, der er sammenfaldende med kornstørrelsesændringen. Arsager til lermineralændringerne skal formodentlig findes i flokkulationsmekanismerne for 


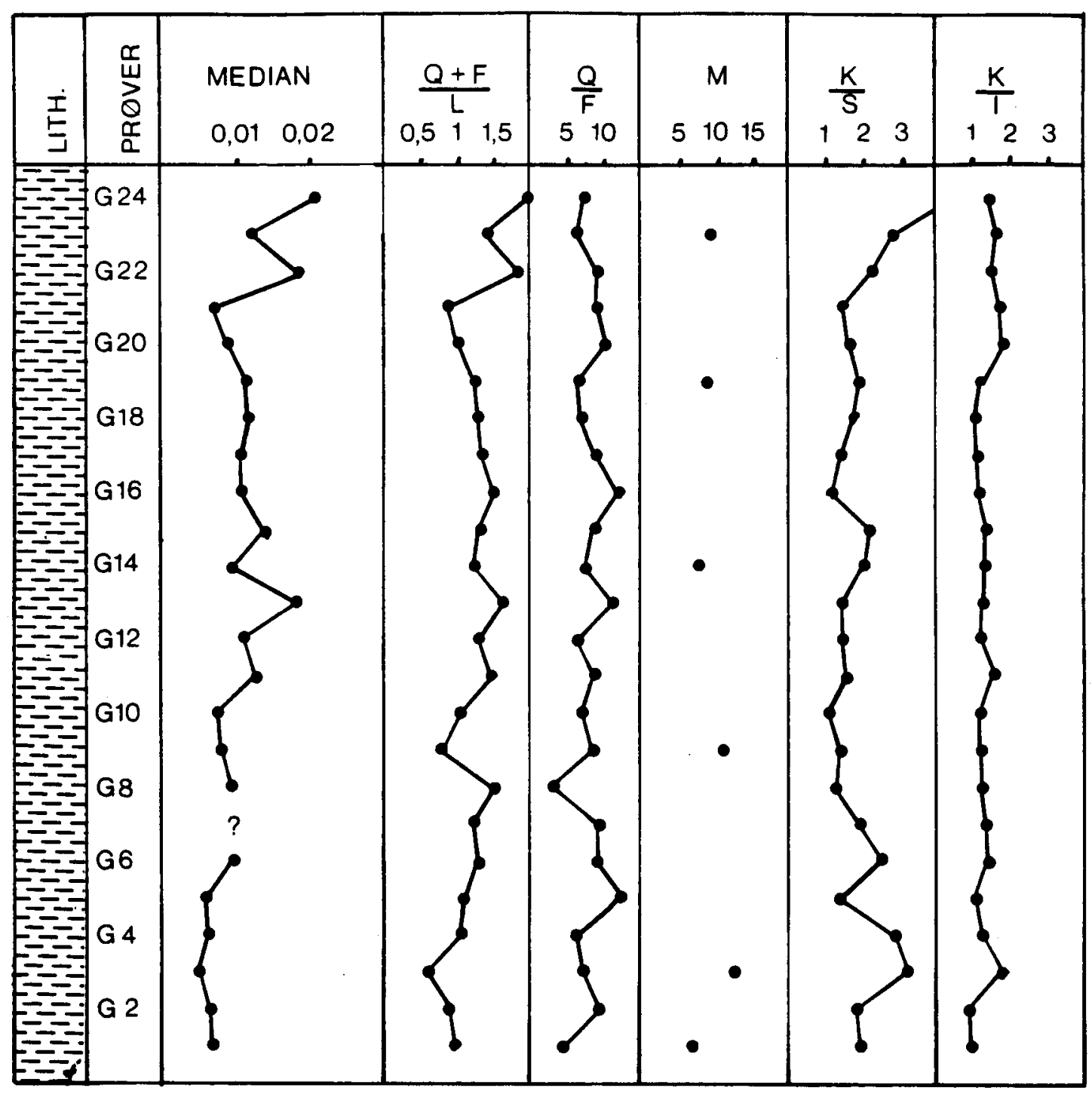

Fig. 19. ratioværdier og kornstørrelsesfordeling i Gram leret. $Q+F / L$ (kvarts+feldspater/lermineraler) er en kornstørrelsesparameter. Q/F (kvarts/feldspater) og $M$ $\left(\mathrm{K}_{2} \mathrm{O}+\mathrm{Al}_{2} \mathrm{O}_{3} / \mathrm{MgO}+\mathrm{Na}_{2} \mathrm{O}\right)$ giver informationer om modenheden af sedimentet, hvor de højeste vardier findes $i$ de mest modne prøver. K/S (kaolinit/smektit) og $\mathrm{K} / \mathrm{I}$ (kaolinit/illit) er lerratioer.

Fig. 19. Ratio-values and grain size distribution through the Gram Clay. Q+F/L (quartz+feldspar/clay minerals) is a grain size parameter. $Q / F$ (quartz/feldspar) and $M$ $\left(\mathrm{K}_{2} \mathrm{O}+\mathrm{Al}_{2} \mathrm{O}_{3} / \mathrm{MgO}+\mathrm{Na2O}\right) \mathrm{gives}$ information on the maturity of the sedinments, with highest values in the most mature samples. $\mathrm{K} / \mathrm{S}$ (kaolinite/smectite) and $\mathrm{K} / \mathrm{I}$ (kaolinite/illite) are clay-ratios. 
lermineraler, $i$ partikelstørrelser og i lermineralernes evne til at optage vand i mellemlagsposition. Laboratoriefors $\varnothing \mathrm{g}$ har vist, at der sker en differentiel flokkulation af lermineraler, når de føres fra en flod med lav salinitet til det mere marine miljø med høj salinitet (Whitehouse et al. 1960). Denne mekanisme vil betyde, at kaolinit vil aflejres tattere på kysten end smektit. Disse forsøg er lavet med rene lermineraler og Gibbs (1977) mener, at differentiel flokkulation ikke spiller nogen større rolle $i$ naturlige miljøer, hvor lermineralerne har metalliske og organiske coatings. Han foreslår, at differentiationen af lermineraler skyldes at kaolinit, illit og smektit generelt har forskellige størrelsesfordelinger, således at smektit har mindste partikelstørrelse fra $0,9 \mu \mathrm{m}$ til under $0,1 \mu \mathrm{m}$, kaolinit er intermediær mellem $10 \mu \mathrm{m}$ og 0,4 $\mu \mathrm{m}$ og illit (+ 10 A glimmer) har et bredt størrelsesspektrum fra sandstørrelse til $0,4 \mu \mathrm{m}$. Mekanismen for lermineraldifferentiationen er da en fysisk sortering, således at smektit aflejres fjernere fra kysten end kaolinit. Endringen $i$ den nederste del af sekvensen kan måske skyldes andringer af dræneringsforholdene i denudationsomrádet. Piasecki (1980) finder, at mængden af terrestisk plantemateriale generelt stiger opad i Gram leret, samtidig med at mængden af dinoflagellatcyster falder. Da marine cyster er tilstede $i$ hele serien, mener han at variationen $i$ terrestisk materiale skyldes variationer $i$ mængden af ferskvandstilførsel til omrádet, d.v.s. ændringer i dræneringen af de tilstødende landområder. En periodisk stigning af ferskvandstilførsel til området kan forklare det højere indhold af kaolinit og/eller gibbsit. Stigningen af begge lerratioerne $\emptyset$ verst i profilet skal sandsynligvis ses i sammenhæng med begyndende kystmigration, sáledes at den øverste del af profilet afspejler mere kystnære forhold.

Det organiske materiale er ikke specielt knyttet til de mere finkornede materialer, som bla. beskrevet af Tissot og Welte (1978), men korrelerer derimod positivt med kornstørrelsen. Dette afspejler sandsynligvis at det orga- 
niske materiale er bevaret p.g.a. en større aflejringsrate. Nielsen et al. (1986) viser at aflejrings raten stiger kraftigt i Øvre Miocæn, over $1 \mathrm{~mm}$ pr. år, i Centralgraven. En forholdsvis $h \phi j$ aflejringsrate synes også at forklare manglende halmyrolytiske processer (glaukonit) og at de fækale pellets er pyritiserede.

Mno-indholdet ligger konstant på ca. 0,03\%. Dette må betragtes som ret lavt, idet sedimentet er bioturberet og der derfor må have været ilt tilstede ved bunden af aflejringsmiljøet. Disse forhold vil normalt medføre høje koncentrationer af MnO. Det lave MnO-indhold afspejler sandsynligvis et anoxisk sedimentmiljø tæt under sedimentvand grænsen (Bjørlykke 1974).

Konkretionerne, som er fundet i Gram leret, ligger i bestemte niveauer, der kan følges $i$ hele graven. Da de undersøgte konkretioner alle indeholder krabber og konkretionsdannelsen er. knyttet til disse, se under diagenesen, må årsagen til den horisontale fordeling nødvendigvis findes $i$ den umiddelbart pludselige optræden af døde krabber. En massedød af krabber kan forklares ved periodiske anoxiske forhold i bundmiljøet, $f$. eks. p.g.a. algeopblomstring eller havniveauændringer (Demaison and Moore 1980).

\section{Diagenese}

I et anoxisk sedimentmiljø dannes en rakke authigene mineraler. I Gram leret er der dannet følgende authigene mineraler: glaukonit, pyrit, calcit og siderit. Dannelsen af disse mineraler er nært knyttet til den bakterielle nedbrydning af organisk materiale og reduktion af $\mathrm{SO}_{4}$, $\mathrm{Mn}^{4+}$ og $\mathrm{Fe}^{3+}$. Disse biologiske og kemiske processer 
medfører en opdeling af sedimentet i zoner (Curtis 1978). I Gram leret har der øverst været en tynd oxisk zone, herunder en anoxisk sulfidisk zone og nederst en anoxisk metanisk zone.

Oxisk zone

Glaukonits authigenese er foregàet i den oxiske zone i fækale pellets. Her har der været tilstrækkeligt med $\mathrm{K}^{+}$og $\mathrm{Fe}^{3+} \mathrm{i}$ havvandet, og $\mathrm{i}$ de fækale pellets har der været degraderede lermineraler, samt ufordøjet organisk materiale, som har skabt det nødvendige redox-forhold (Burst 1958). En høj aflejringsrate har dog medført, at der kun er dannet en ringe mangde glaukonit.

Anoxisk sulfidisk zone

I den sulfidiske zone sker reduktionen af $\mathrm{SO}_{4}, \mathrm{Mn}^{4+} \circ \mathrm{og} \mathrm{Fe}{ }^{3+}$ ved bakterielle processer, hvor det organiske materiale bruges som oxidationsmiddel. Under denne proces frigøres $\mathrm{CO}_{2}$ og $\mathrm{HCO}_{3}^{-}$. Processen forløber indtil der ikke er mere $\mathrm{SO}_{4}$ i sedimentet.

I det anoxiske-sulfidiske miljø dannes monosulfider ved reaktionen;

$$
\mathrm{Fe}^{2+}+\mathrm{H}_{2} \mathrm{~S} \longrightarrow \mathrm{FeS}+2 \mathrm{H}+
$$

Ved tilførsel af s0 dannes disulfider, pyrit (Berner 1964; Berner 1970). Pyrits authigenese er derfor afhængig af tre komponenter: tilstedeværelsen af metaboliserbart organisk materiale, reaktivt jern og svovl. Et plot $i$ et C/S-diagram ( $\mathrm{fig}$. 20) viser at regressionslinien gennem 
punkterne rammer positivt på aksen for organisk materiale og negativt på svovl-aksen. Dette antyder at svovl har været en begrænsende faktor for pyritdannelsen (Sweeney et al. 1987). En palynologisk undersøgelse af det organiske materiale viser bl.a. at dette er ret velbevaret. Arsagen hertil er sandsynligvis en høj aflejringsrate (pers. medd. Raunsgaard og Dybkjær). De pyritkorn, der er observeret i mikroskopundersøgelsen, har alle haft en framboid form. Dette er karakteristisk for pyrit, der er dannet, hvor der har været tilstrækkeligt med reaktivt jern (Raiswell 1982). At der har været rigeligt med reaktivt jern underbygges af at der har været jern $i$ overskud til siderits authigenese.

Sedimentets passage gennem den anoxiske-sulfidiske zone er sket forholdsvis hurtigt p.g.a. en høj aflejringsrate, der har begrænset diffusionen af $\mathrm{SO}_{4}$ ned i sedimentet.

SVOVL

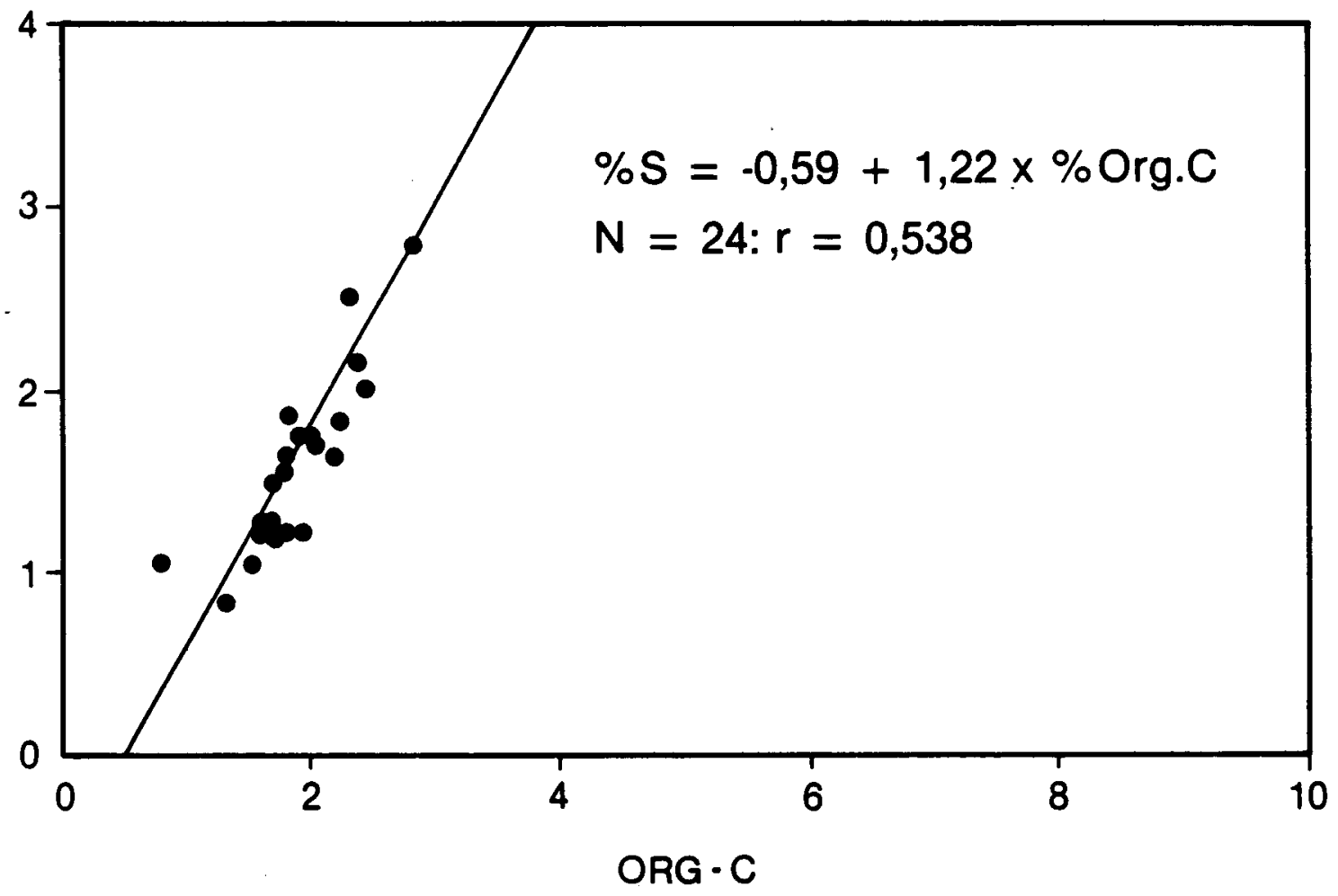

Fig. 20. C/S plot med vægt procent organisk kulstof mod vægt procent svovl i Gram leret. regressionslinien rammer positivt pá aksen for organisk kulstof.

Fig. 20. C/S plot of weight percent organic carbon versus weight percent sulphur for the Gram Clay. The regression line has a positive intercept on the organic carbon axis. 
Anoxisk metanisk zone

Under den anoxiske-sulfidiske zone fortsætter den bakterielle nedbrydning og opkoncentreringen af $\mathrm{HCO}^{3-}, \mathrm{CO}_{2}$ og $\mathrm{Fe}^{2+}$, hvis der stadigt er tilstrækkeligt med reaktivt jern, disse vil reagere og danne jernkarbonat, siderit (Curtis 1983).

I Gram leret er sideriten kun detekteret i konkretionerne, der er beliggende $i$ veldefinerede horisonter. Konkretionerne indeholder aftryk af krabber, og konkretionsdannelsen anses derfor at være nært knyttet til nedbrydningen af disse.

Konkretioner med dyr eller planterester er ofte beskrevet $i$ litteraturen, bl.a. Lippmann (1955). Konkretionsdannelsen er tæt relateret til nedbrydningen af det organiske materiale, hvor der opstår alkaline forhold $i$ et lokalt område (Lippmann 1955; Berner 1968), hvilket medfører udfaldning af karbonater. Konkretionerne fra Gram leret består hovedsagligt af siderit (fig. 6) men der er også detekteret calcit, især i konkretion B. Hvorvidt dette skyl- des en zonering af konkretionerne er ikke undersøgt i narvarende rapport, men det er karakteristisk at de alle indeholder siderit og calcit.

Konkretionsdannelsen er sket hurtigt, idet krabberne ikke er deformerede. Den forste karbonatudfaldning er sandsynligvis startet allerede $i$ den sulfidiske zone, hvor ammoniakdannelsen ved nedbrydningen af krabber skaber alkaline forhold. Omdannelsen fra monosulfider til disulfider og reduktionen af jern hæver ligeledes $\mathrm{pH}$. De her udfældede karbonater vil være jernfattige, da reduceret jern foretrukkent vil indga $i$ dannelsen af pyrit (Curtis 1983). Senere $i$ diagenesen, $i$ det metaniske miljø, udfældes siderit.

Aflejringsmilje og diageneseforhold for Gram leret er illustreret $i$ figur 21 og 22 . 


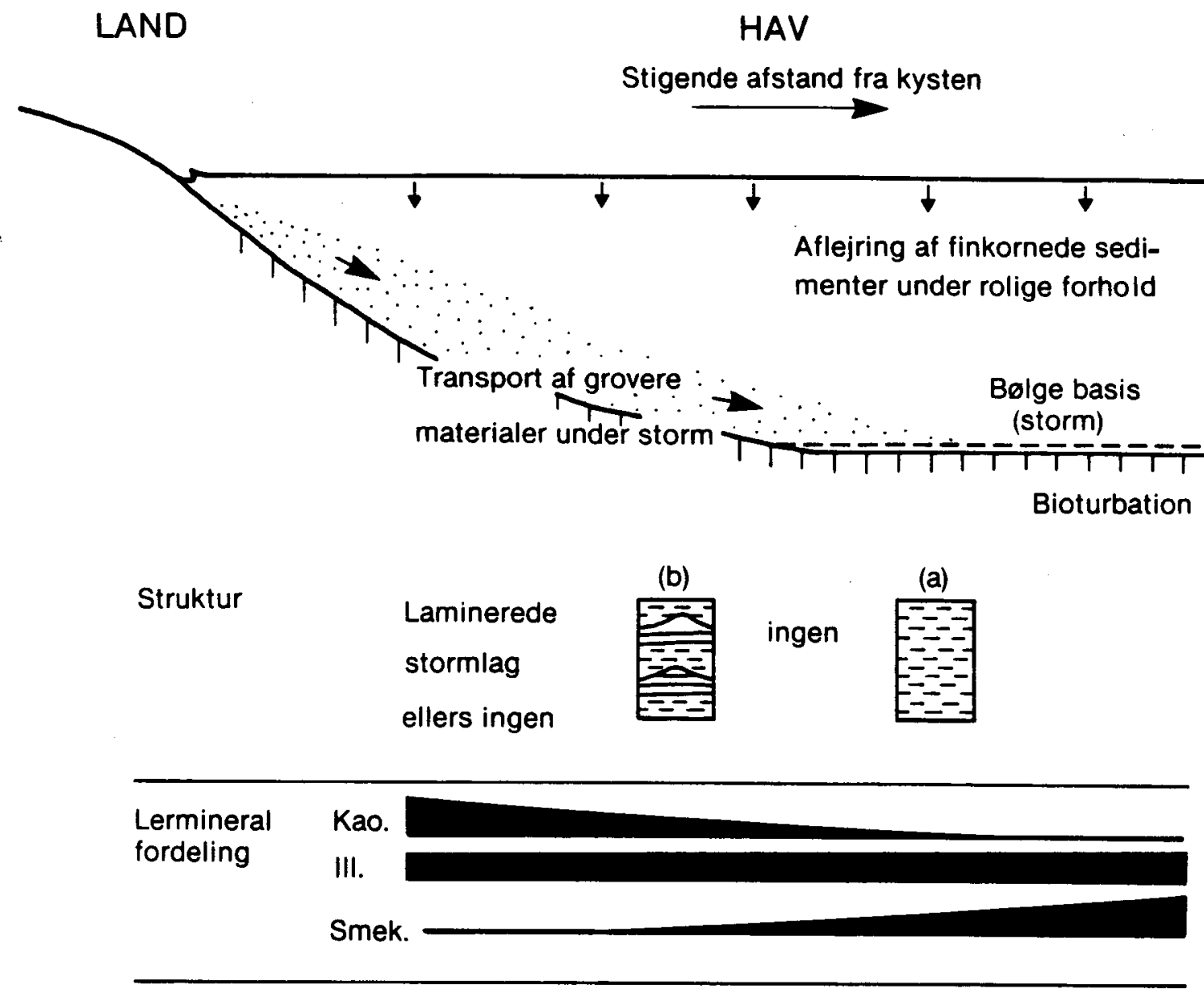

Fig. 21. Foreslået model for aflejring af Gram leret. I normale situationer aflejredes det mest finkornede sediment, såsom lermineraler, under lave energiforhold. I stormperioder aflejredes det groveste materiale i stormlag. Langst fra kysten er de fleste stormlag homogeniseret ved bioturbation, med dannelse af et strukturløst sediment (a). Tættere pá kysten var sedimentationsraten tilstrækkelig $h ø j$ til at nogle stormlag beskyttedes mod bioturbation (b). Kaolinit og ilit aflejredes tæt pá kysten og smektit fjernere fra kysten.

Fig. 21. Proposed depositional model for the Gram Clay. In normal situations the most finegrained sediments were deposited, e.g. clay minerals, at ralatively low energy conditions. In stormy weather, the most coarsegrained material was deposited in storm layers. Far from the coast most of the laminated storm layers were homogenized by bioturbation, resulting in a structureless sediment (a). Near the coast the rate of sedimentation was sufficient to protect some of the storm layers from bioturbation (b). The kaolinite and illite was deposited more proximal to the coast than smectite. 


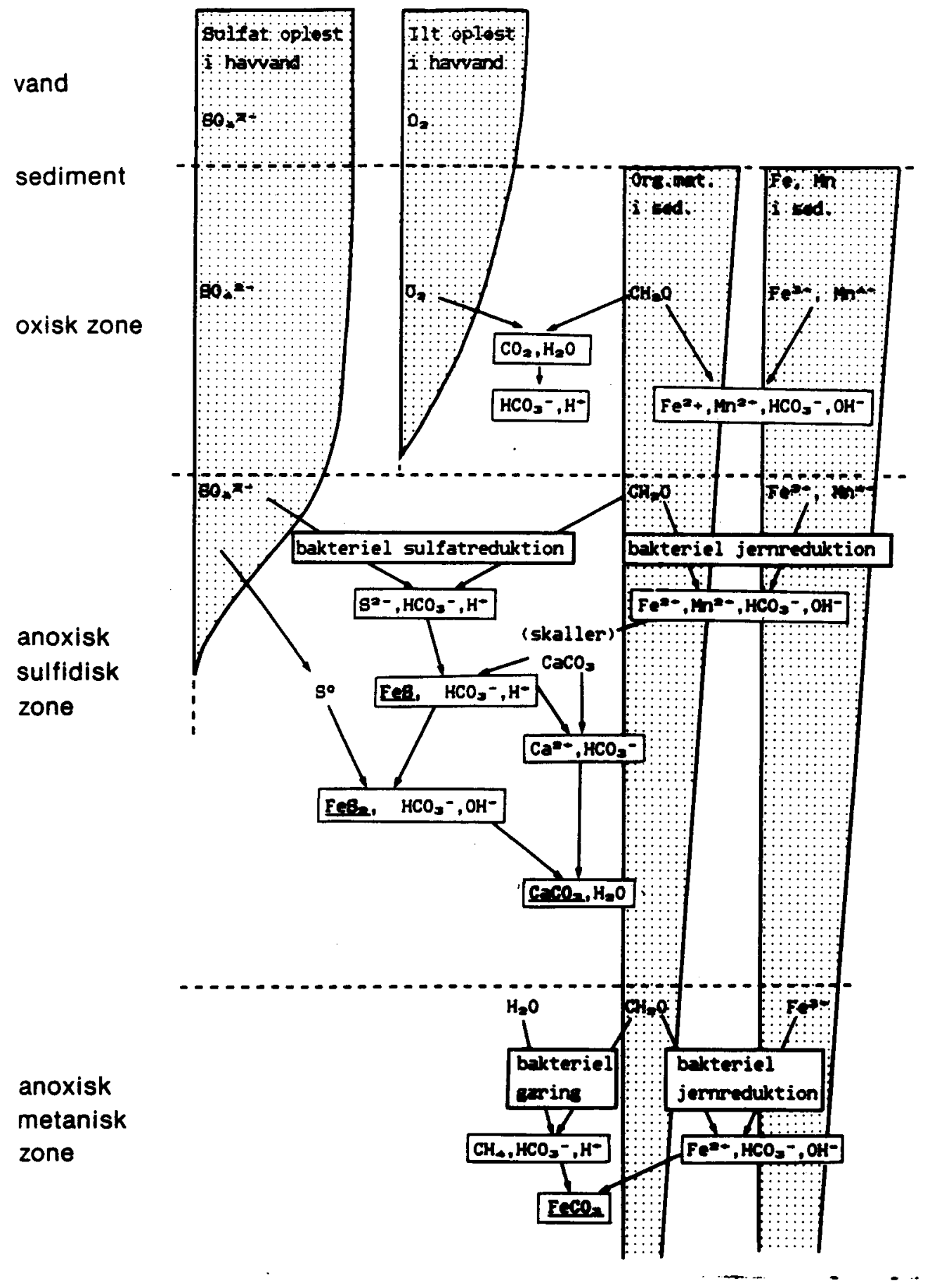

Fig. 22. Foreslået diagenetisk model for Gram leret. Modellen $v$ iser inddeling af det finkornede sediment i dybdezoner samt de biologiske og kemiske reaktioner, der er relateret til de enkelte dybdezoner. Figuren er baseret pá oplysninger fra Curtis (1978).

Fig.- 22. Proposed diagenetic model for the Gram Clay, with subdivision of the fine-grained sediment in depthrelated zones and the biological and chemical reactions occuring in the individual zones. The figure is based on informations from Curtis (1978). 
Det $\emptyset$ vre miocæne Gram ler udgøres hovedsagligt af omlejrede ældre tertiære sedimenter. Tidligere undersøgelser af de miocæne formationer viser, at kildeområder i høj grad er det skandinaviske område, og tilførsien er foregået via den nuværende $\emptyset$ sters $\varnothing$ (Koch et al., 1973).

Gram leret indeholder gibbsit, der formodentlig stammer fra eocæne sedimenter og tilstedeværelsen af gibbsit indikerer, at en del af sedimentet kun er transporteret kort vej fra kildeområdet til aflejringsområdet.

Det marine sedimentationsmiljø var karakteriseret ved relativt lavt energiniveau under aflejring af det lerede materiale, hvorimod det grovere materiale er aflejret $i$ stormperioder. Sekvensen afspejler formodentlig en prograderende kystlinie med stigende energiniveau opad $i$ sekvensen. Dette resulterede $i$ en gradvis overgang fra bioturberede lerede sedimenter til hyppigere indslag af laminerede bølgepávirkede stormlag.

Lermineralogien indikerer ligeledes en progressiv faldende afstand til kystlinien opad $i$ sekvensen med stigende kaolinit/smektit forhold. Et niveau i den nedre del af sekvensen med højt kaolinit/smektit forhold skyldes formodentlig variationer $i$ dræneringsforhold, således at omrádet $i$ en periode har været mere direkte pàvirket af udstrømmende flodvand.

Bundforholdene har hovedsagligt varet oxiske med tilstedeværelse af en rig bundfauna til at give intens bioturbation af sedimentet. Bundfaunaen har endvidere betinget en pelletisering af en del af sedimentet. De fækale pellets er svagt glaukonitiserede, formodentig på sedimentoverfladen. 
Kortvarige anoxiske forhold er opståt på bunden og er resulteret $i$ massedød af bundlevende krabber. Disse krabber ligger i veldefinerede horisonter $i$ sedimentet.

Tæt under sediment-vand grænsen opnåedes anoxiske forhold som resultat af nedbrydning af organisk materiale ved iltforbrugende bakterier. Den videre nedbrydning af organisk materiale er hovedsagligt foregået ved sulfatreducerende bakterier med samtidig reduktion af reaktivt jern i sedimentet. De vigtigste reaktionsprodukter heraf er $\mathrm{H}_{2} \mathrm{~S}, \mathrm{~S}, \mathrm{Fe}^{2+}, \mathrm{Mn}^{2+}$ og $\mathrm{CO}_{2}$.

I dette sulfidiske miljø dannes først jernmonosulfider, der senere reagerer med elementar svovl $i$ dannelsen af pyrit. Pyritiseringen var mest intens $i$ pellets og $i$ gravegange. Lokale alkaliske miljøer opstod omkring krabber, p.g.a. ammoniakdannelse ved deres forrádnelse. I disse alkaliske miljøer udfaldedes calcit stedvist som konkretioner. Alt tilstedeværende reduceret jern vil foretrukkent indgà i dannelse af pyrit.

Den begrænsende faktor for pyritdannelsen, og dermed sedimentets ophold i det sulfidiske miljø, har været svovl. En høj aflejringsrate har bevirket, at sedimentet relativt hurtigt er blevet begravet til dybder, hvor sulfatdiffussionen er ophørt.

Nedbrydning af resterende organisk materiale foregár herefter ved bakterielle gæringsprocesser med dannelse af methan og bikarbonat. Fortsat reduktion af reaktivt jern i sedimentet giver generelt højere $\mathrm{pH}$.

I dette methaniske miljø vil reduceret jern foretrukkent reagere med bikarbonat i dannelse af siderit. Udfældning af siderit sker i konkretioner omkring krabber, hvor det mest alkaliske miljø er tilstede.

De diagenetiske processer i Gram leret er sáledes relateret til den tidlige diagenese. 
The Upper Miocene Gram Clay mainly consists of reworked older Tertiary sediments. Previous investigations show, that Scandinavia was the most important source area for the Miocene Formations, with drainage mainly through the present Baltic Sea (Koch et al., 1973).

Gibbsite contained in the Gram Clay has probably been derived from Eocene sediments and its presence indicates short transport length for parts of the sediment.

The clayey sediments were deposited in a relatively low energy marine environment, and deposition of the more coarse grained material occured in periods of storm. The sequence probably reflects a prograding coast with increasing energy level towards the top, resulting in a transition from intensively bioturbated muds to generally more coarse grained sediments with numerous intercalations of laminated wave influenced storm deposits.

Indications from clay mineralogy shows the same trend, where increasing kaolinite/smectite-ratio towards the top reflect a progressive proximity to the coastal line. High kaolinite/smectite-ratio in a lower level in the sequence probably is related to variations in drainage patterns, with temporary more direct influence of fresh water drainage.

Oxic conditions prevailed on the sediment surface, which maintained a rich benthonic fauna and intensive bioturbation of the uppermost layers. Fecal pellets from this fauna were weakly glauconitized close to or at the sediment surface. 
Temporary anoxic events resulted in mass mortality of bottom living crabs. The crabs are present in well defined horizons in the sediment.

Anoxic conditions appeared close under the sediment-water interface as a result from aerob bacterial degradation of organic matter. In this anoxic environment continued degradation of organic matter was executed by sulphate reducing bacteria accompanied with reduction of reactive iron in the sediment. Reactions mainly produced $\mathrm{H}_{2} \mathrm{~S}, \mathrm{~S}, \mathrm{Fe}^{2+}, \mathrm{Mn}^{2+}$ and $\mathrm{CO}_{2}$.

The first formed minerals in this environment were iron monosulphides, which subsequently reacted with elementary sulphur in the precipitation of pyrite. Ammonium produced by the degradation of crabs resulted in lokal alkaline environments, where precipitation of calcite in concretions could occur. All available reduced iron would enter in the formation of pyrite.

The amount of sulphur was the limiting factor for pyrite precipitation and, as a consequence, for the thickness of the sulphate reducing zone. High rate of deposition resulted in rapid burial and cessation of sulphate diffusion from overlying seawater.

Below this zone organic matter degradation continues via bacterial fermenters with production of methane and bicarbonate. Continued reduction of available iron lead to higher $\mathrm{pH}$.

In this bacterial fermentation zone reduced iron reacts with bicarbonate in the precipitation of siderite as concretions around crabs. The selectivity of this precipitation is related to high alkalinity in the vicinity of ammonium produced by degradation of crabs.

Diagenetic processes in the Gram Clay is thus related to early diagenesis. 
Andreasen, A.D., 1985: En sedimentologisk unders $\varnothing$ gelse af $\emptyset$. Oligocæn-N. Miocæn ved Bjerringbro og Ulstrup, Midtjylland. Upubl. specialeopgave, Aarhus Universitet, $150 \mathrm{pp}$.

Berner, R.A., 1964: Stability fields of iron minerals in aerobic marine sediments. Jour. Geol. Vol. 72, nr. 6, p. $826-834$.

Berner, R.A., 1968: Calcium carbonate concretions formed by the decomposition of organic matter. Science, Vol. 159, p. 195-197.

Berner, R.A., 1970: Sedimentary pyrite formation. Am. Jour. Science 268 , p. 1-23.

Beyer, C., 1987: Øvre Oligocæn - Nedre Miocæn i Nordvest Jylland. Facies analyse og Magnetostratigrafi. Upubl. specialeopgave, Aarhus Universitet, 164 pp.

Biscaye, P.E., 1965: Mineralogy and sedimentation of Recent deepsea clay in the Atlantic Ocean and adjacent seas and oceans. Bull. geol. Soc. Am., Vol. 76, No. 7, p. 803-832.

Bjørlykke, K., 1974 : Depositional history and geochemical composition of Lower Palaeozoic epicontinental sediments from the Oslo Region. N.G.U., Nr. 305, 76 pp.

Buchardt, B., 1978: Oxygen isotope palaeotemperatures from the North Sea area. Nature, Vol. 275, No. 5676, p. $121-123$.

Burst, J.F., 1958: "Glauconite" Pellets: Their mineral nature and applications to stratigraphic interpretations. Bull.Am. Ass. Pet. Geol., Vol. 42, No. 2, p. 310-327.

Cohen, E., 1952: The nature of silicates and carbonates of iron in the Northampton Sand Ironstone of Central England. 19'th. Int. Geol. Congr. Algier 1952: Symposium surles gisements de fer du monde, p. 466-471.

Curtis, C.D., 1978: Possible links between sandstone dia- 
genesis and depth-related geochemical reactions occurring in enclosing mudstones. J. geol. Soc. Lond., 135, p. 107-117.

Curtis, C.D., 1983: Geochemistry of porosity enhancement and reduction in clastic sediments. In: Brooks: Petroleum Geochemistry and Exploration of Europe.

Geol. Soc. Spec. Publ. No. 12, p. 113-125.

Demaison, G.J. and Moore, G.T., 1980: Anoxic environments and oil source bed genesis. Bull. Am. Ass. Pet. Geol., Vol. 64, No. 8, p. 1179-1209.

Dinesen, B. 1976: Geochemical properties of the marine younger miocene at Gram, SW Jutland. Danm. Geol. Unders., A rbog 1975, pp 5-29.

Dypvik, H., 1984: Geochemical compositions and depositional conditions of Upper Jurassic and Lower Cretaceous Yorkshire Clays, England. Geol. Mag., Vol. 121, No. 5, p. $357-374$.

Gibbs, R.J., 1977: Clay mineral segregation in the marine environment. Jour. Sed. Petr., Vol. 47, p. 237-243.

Koch, B.E., Friedrich, W.L., Christensen, E.F., Friis, E.M., 1973: Den miocæne brunkulsflora og dens geologiske miljø i Søby-Fasterholt området syd-øst for Herning. Danm. Geol. Foren., Arskrift 1972, 157 pp.

Krutsch, W. \& Majewski, J., 1967: Zur Methodik der pollenstratigraphischen zonengliederung im JungtertiärMitteleuropas. Abh. Zentr. geol. Inst. H. 10, p. 83-98. Berlin.

Larsen, G. og Dinesen, A., 1959: Vejle Fjord Formationen ved Brejning. Sedimenterne og foraminiferfaunaen (Oligocæn Miocæn). Danm. Geol. Unders., II Række, Nr. 82, 100 pp. Lippmann, F., 1955: Ton, geoden und minerale des Barrêmevon Hoheneggelsen. Geolog ische Rundschau, Vol. 43, No. 2, p. 475-503.

Nielsen E.F., 1983: En sedimentologisk og geokemisk undersøgelse af Hodde Formationen, Miocæn. Upubl. specialeopgave, Aarhus Universitet, $245 \mathrm{pp}$.

Nielsen, 0.B., Sørensen, S., Thiede, J. og Skarbø, 0., 1986: Cenozoic differential subsidence of the North Sea. Bull. Am. Ass. Pet. Geol., Vol. 70, No. 3, p. 276-298. Pedersen, G.K., 1985: Thin, fine-grained storm layers in a 
muddy shelf sequence: an example from the Lower Jurassic in the Stenlille 1 well, Denmark. J. geol. Soc. Lond., 142 , p. $357-374$.

Piasecki, S., 1980: Dinoflagellate cyst stratigraphy of the Miocene Hodde and Gram Formations, Denmark. Bull. geol. Soc., Denmark, 29. p. 53-76.

Radwanski, A., Friis, H. og Larsen, G., 1975: The Miocene Hagenør-Børup sequence at Lillebælt. Bull. geol. Soc., Denmark, Vol. 24, No. 3-4., p. 283-297.

Raiswell, R., 1982: Pyrite texture, isotopic composition and the availability of iron. Am. Jour. Science, Vol. 282, p. $1244-1263$.

Rasmussen, L.B., 1961: De Miocæne Formationer i Danmark.

Danm. Geol. Unders., IV. Række, Bd. 4, Nr. 5, 45 pp. Rasmussen, L.B.: 1966 Molluscan faunas and biostratigraphy of the marine Younger Miocene Formations in Denmark. Danm. Geol. Unders., 2 Rk., No. 88, 358 pp. Rasmussen, L.B., 1979: The Stratigraphy of the Marine Neogene of Denmark. In: Proceedings of the Symposium: The continental Miocene of Central Jutland, Denmark. Aarhus University, June the 11'th. - 16'th., 1979, p. 11-21. Rasmussen, E.S., 1987: En mineralogisk og geokemisk unders $\varnothing$ gelse af Vejle Fjord Formationen ( $\emptyset$.Oligocæn-N. Miocæn). Upubl. specialeopgave ved Aarhus Universitet, $214 \mathrm{pp}$.

Reineck, H. E. and Singh, I. B. 1980: Depositional Sedimentary Environments. pp 339-370. Springer-Verlag Berlin, Heidelberg og New York.

Schultz, L. G., 1964: Quantitative interpretation af mineralogical composition from $x$-ray and chemical data for for the Pierre Shale. Prof. Paper U. S. Geol. Surv. $391 \mathrm{C} .31 \mathrm{pp}$.

Sweeney, M., Turner, P. and Vaughan, P.J., 1987: The Marl Slate: a model for the precipitation of calcite, dolomite and Sulphides in a new ly formed anoxic sea. Sedimentology, 34, p. 31-48.

Tissot, B.P. and Welte, D.H., 1978: Petroleum formation and occurrence. p. 1-74. Springer-Verlag, New York.

Velde, B., 1985: Clay minerals: A Physico-Chemical explanation of their Occurrence. Developments in sedimentology, 
40. Elsevier, p. 52-58.

Whitehouse, U.G., Jeffrey, L.M. and Debbrecht, J.D., 1960:

Differential settling tendencies of clay minerals in saIine waters. Clays and Clay Min. (7th Nat. Conf. 1958), p. $1-74$.

Tak

Forfatterne $\varnothing$ nsker at takke Leif Banke Rasmussen, Danmarks Geologiske Undersøgelse, der har muliggjort denne publikation, lektor Ole Bjørslev Nielsen, Geologisk Institut, Aarhus Universitet, for frugtbare diskussioner, museumsdirektør Flemming Roth og personalet ved Gram $\mathrm{Mu}-$ seum, samt Søren Bo, Jette, Bente, Ulla, Therese, Lis, Geologisk Institut ved Aarhus Universitet. Endvidere gives en tak til Sønderjyllands Amt for finansiel støtte til projektet. 
Metodebeskrivelse

Kornstørrelsesanalyse

Prøverne vådsigtedes gennem en $63 \mu \mathrm{m}$-sigte. Fraktionen $>63$ $\mu \mathrm{m}$ blev tørret og vejet. Kornstørrelsesfordelingen af $<63 \mu \mathrm{m}$ fraktionen blev bestemt på Andreassen-cylinder. Prøverne behandledes med ultralyd, og haldtes på Andreassen-cylinder, der var tilsat $10 \mathrm{ml}(1,5 \%)$ peptisator, $\left(\mathrm{NaPO}_{3}\right)_{6}$ og fyldtes til $15 \mathrm{~cm}$-mærket.

Princippet ved analysen er, at partiklerne antages at falde med konstant hastighed, sà man ved $h j æ l p$ af stokes lov kan beregne faldtiden for en partikel med en given ækvivalent sfærisk diameter. Det er vigtigt at holde en konstant temperatur (stuetemperatur), idet den har indflydelse på væskens viskositet.

Stokes lov: $t=\frac{18 \times \mathrm{y} \times 10^{7} \times \mathrm{h}}{8 \times(\mathrm{D} 1-\mathrm{D} 2) \mathrm{d}^{2}}$

$t=$ faldtiden i sec.

$g$ = tyngde acc. i cm. $/ \mathrm{sec}^{2}$

$\mathrm{y}=$ vands viskositet $\mathrm{i} \mathrm{g} / \mathrm{cm}$. sec.

D1 = partikeldensitet $i \mathrm{~g} / \mathrm{cm}^{3}$

D2 = vands densitet $i \mathrm{~g} / \mathrm{cm}^{3}$

$\mathrm{h}=\mathrm{faldh} \phi j \mathrm{jle} \mathrm{i} \mathrm{mm}$.

$d=$ ækvivalent diameter i $\mu \mathrm{m}$.

Det antages at partiklen er sfærisk med massefylde på $2,65 \mathrm{~g} / \mathrm{cm}$. 
Ved at udtage prøver til bestemte tidspunkter, som er beregnet ved hjælp af Stokes lov, og sammenholde vægten af disse med vagten af en 0-prøve, der tages umiddelbart efter cylinderne er rystet, udregnes kornstørrelses fordelingen af siltfraktionen. Resultaterne er anført i Appendix 2, Tabel D.

Bulkmineralogisk analyse

Et par gram af det nedknuste materiale blev lagt i en aluminiumsramme (uorienteret prøve) og blev kørt pá røntgendiffraktometeret fra $2^{\circ}$ til $65^{\circ} 2 \theta$.

Kvalitativ analyse: Vinklen mellem røntgenstrålen og præparatets overflade udmáltes pà diffraktogrammet for de forskellige peaks. Udfra kendskabet til $\lambda$ (bølgelængde af røntgenstrálen) brugtes Braags lov (se herunder) til at finde den gitterplansafstand (d), der svarer til de enkelte peaks.

Hvert enkelt mineral har nogle karakteristiske gitterplansafstande, svarende til forskellige krystalflader. Disse værdier fandtes i de sákaldte ASTM-kort, der anvendes til identifikation af mineralerne.

$$
\text { Braag's lov: } \quad 2 d=\frac{n \times \lambda}{\sin \theta}
$$

Kvantitativ analyse: Mineralerne blev kvantificeret udfra peakhøjden, der udmåltes $i$ cps (counts per second) over basislinien og korrigeredes med en intensitetsfaktor, se tabel 1. Værdierne omregnedes så summen gav $100 \%$. Resultaterne findes i Tabel A, Appendix 2. 
Eksempler på røntgendiffraktogrammer ses på figur 4 .

\begin{tabular}{|lcl|}
\hline Mineral & Intensitetsfak. & $\mathrm{d}$ \\
\hline Lerm. & 100 & 4,5 \\
Kalifeldspat & 1000 & 3,25 \\
Plagioklas & 1000 & 3,3 \\
Calcit & 1000 & 3,03 \\
Calcit mix. & 1000 & 2,95 \\
Dolomit & 1000 & 2,9 \\
Siderit & $1200-2000 !$ & 2,81 \\
Pyrit & 1200 & 2,71 \\
Kvarts & 400 & 4,25 \\
\hline
\end{tabular}

Tabel 1: Gitterplans afstand og intensitetsfaktorer. ! afh. af sideritindhold.

Table 1: Distance between lattice layers and intensity factors. ! dependent of amount of siderite.

Lermineralogisk analyse

Fraktionen mindre end $2 \mu \mathrm{m}$ blev udskilt på glascylindre, $i$ hvilke prøvematerialet var bragt i suspension. Efter en $i$ forvejen beregnet tidsperiode, hvor $>2$ um-fraktionen var sunket til bunds, tømtes cylindrene for fraktionen $<2 \mu \mathrm{m}$. Prøverne til lermineralogi-analysen blev tilsat en skefuld $\mathrm{NaCl}$ og centrifugeredes. Proceduren blev gentaget indtil vandet $i$ cylindrene var klart.

Lidt af <2 $\mu \mathrm{m}$-fraktionen blev dryppet på en glasplade og tørret natten over (orienterede prøver). De ubehandlede præparater blev kørt pa rontgendiffraktomereret, Phillips PW 1710, fra $2^{\circ}$ til $65^{\circ} \quad 2 \theta$. Herefter behandledes 
lerpræparaterne med ethylenglycol og kørtes fra $2^{\circ}$ til $20^{\circ} 2 \theta$. Tilsidst opvarmedes præparaterne til $300^{\circ}$ og $550^{\circ} \mathrm{C}$ og kørtes fra $20^{\circ}$ til $26^{\circ} 2 \theta$.

Refleksioner ved $12-15 \AA$, der ved glucollering flyttedes til $17 \AA$, blev tilskrevet smektit.

Refleksioner ved $10 \AA$, der ikke påvirkedes af glycollering og opvarmning, blev tilskrevet illit.

Refleksioner ved $7 \AA$, der ikke påvirkedes af glycollering, blev tilskrevet kaolinit og klorit. Beregning af kloritindholdet blev foretaget udfra klorit's 14 A reflektion, der forstærkes ved opvarmning til $550^{\circ} \mathrm{C}$.

For ethylenglycollerede præparater beregnedes arealerne af $17 \AA-, \quad 10$ - og 7 -refleksionerne ved multiplikation af peak-højde over basislinie med bredden $i$ den halve højde. Arealerne blev korrigeret med en empirisk bestemt faktor, som ses i tabel 2 (Schultz, 1964; Biscay, 1965; pers. medd. Ole Bjørslev Nielsen).

Summen af de beregnede arealer blev sat til 100\% • 17 A arealet blev tilskrevet smektit, $10 \AA$ korrigeret areal blev tilskrevet illit og 7 A korrigeret areal blev tilskrevet kaolinit og klorit. Forholdet kaolinit/klorit fandtes ved $\mathrm{flg}$. sammenhmng:

Klorit-andelen af den samlede $7 \AA$ andel $=$

$$
\frac{14 \AA(550) \text { peakh } \varnothing \text { jde. }}{1,5 \times 7 \AA \text { (ubeh.) peakh } \varnothing \text { jde. }}
$$

Eksempler på diffraktogrammer af lerfraktionen ses pà figur 3. Resultaterne findes i Appendix 2, Tabel B. 


\section{Arealet af 17 A korrigeres med en faktor på : 1 Arealet af 10 A korrigeres med en faktor på : 3 Arealet af $7 \AA$ korrigeres med en faktor på : 1,15}

Tabel 2: Korrektionsfaktorer til semi-kvantitativanalyse.

Table 2: Correction factors for semi-quantitative analysis.

Geokemi

Grundstofbestemmelse: Grundstofferne $\mathrm{Ca}, \mathrm{Mg}, \mathrm{Mn}, \mathrm{K}, \mathrm{Fe}, \mathrm{Na}$ og Al, samt $S i$ pà prøver af lerfraktionen, er bestemt pá atomabsorptionsflammespektrofotometer PerkinElmer 5000 .

Til totalkemi afvejedes 0,25 gram af det tørrede og knuste prøvemateriale.

$0,5 \mathrm{ml}$ perchlorsyre samt $5 \mathrm{ml}$ flusssyre blev tilsat som reaktionsblanding til den afvejede prøvemangde. Dette inddampedes pá sandbad $\left(200^{\circ} \mathrm{C}\right)$ og en ny portion reaktionsblanding tilsattes og inddampningen blev gentaget (ialt 2-3 gange).

Inddampningsresten fugtedes med 2-3 ml konc. $\mathrm{HCl}$, vand tilsattes og saltene blev bragt $i$ opløsning red opvarming. Heraf fremstilledes passende fortyndinger til bestemmelse pá Perkin Elmer.

Kulstofbestemmelse: Der afvejedes ca. 0,2 gram af det tørrede og knuste materiale, som herefter afbrændtes $i$ LECO-ovnen. Den frigjorte $\mathrm{CO}_{2}$ absorberedes $i$ et filter og blev vejet til bestemmelse af total \& $\mathrm{C}$. 
Et par gram prøve behandledes med $10 \% \mathrm{HCl}$, så $\mathrm{CaCO}_{3}$ blev opløst (det antages at alt $\mathrm{CO}_{3}$ sidder bundet i $\mathrm{CaCO}_{3}$ ). 0,2 gram af den $\mathrm{HCl}$-behandlede prøve afbrændtes i LECO-ovnen og den absorberede $\mathrm{CO}_{2}$ blev vejet.

Det blev således muligt at beregne procentandelen af organisk kulstof og $\mathrm{CaCO}_{3}$ ved følgende formler:

$$
\begin{aligned}
& * \mathrm{C}_{\text {tot }}=\frac{\text { gram } \mathrm{CO}_{2} \times 12,01 \times 100}{44,01 \times \text { gram prøve }} \\
& \% \mathrm{C}_{\text {org }}=\frac{q \mathrm{C} \times \text { gram efter } \mathrm{HCl}}{\text { gram før HCl}} \\
& \% \mathrm{CaCO}_{3}=\frac{\left(\% \mathrm{C}_{\text {tot }}-\% \mathrm{C}_{\text {org }}\right) \times \text { molvægt } \mathrm{CaCO}_{3}}{\text { molvægt C }}
\end{aligned}
$$


Svovibestemmelse: Af det knuste og tørrede prøvemateriale afvejedes en passende mængde. Prøven afbrændtes i LECO-ovnen. Forbrændingsproduktet, hovedsageligt $\mathrm{SO}_{2}$, blev titreret med $\mathrm{KIO}_{3}$. Svovlindholdet bestemtes ved f $\varnothing$ lgende formel:

$$
\% S=\left(\text { forbr. } \mathrm{KIO}_{3}(0,444 \mathrm{~g} / 1)-\text { forbr. til } \mathrm{Fe}(\mathrm{acc})\right) \times \mathrm{Ig}
$$

gram prøve

Afvigelser fra middeltallet.

$$
\begin{array}{r}
\mathrm{Ca}, \mathrm{Mg}, \mathrm{K} \text { og Al: } 1 \% \\
\mathrm{Fe}: 2 \% \\
\mathrm{Na}: 3 \% \\
\mathrm{C}_{\text {org }}: 4 \% \\
\mathrm{~S} \text { og } \mathrm{Mn}: 5 \%
\end{array}
$$

Resultaterne findes i Appendix 2, Tabel $C$.

\section{Radiografi}

En del af profilet blev rengjort, således at det var lodret. Herefter afmmrkedes rammens omrids pà den rengjorte del af profilet. Med forsigtighed blev prøven tilskåret ved langsomt at nærme sig det afmærkede omrids af rammen. Efter tilskæringen monteredes rammen. Inden påsætning af frontpladen blev overfladen jæunet. Orienteringen af prøven markeredes på frontpladen. Prøven blev herefter frigjort med staltrád fra profilet og jæunedes. Tilsidst påsattes bagpladen og prøven blev pakket grundigt ind i plastikposer.

Prøven blev behandlet umiddelbart efter hjemkomsten, da 
det er vigtigt, at behandlingen foretages hurtigt, så prøven ikke tørrer ind.

En prøvekasse blev lagt på en Kodak røntgenfilm (X-Omat MA $2430 \mathrm{~cm}$ ) Og kørtes i røntgenapperatet ca. 14 minutter $(40 \mathrm{kV} ; 4,5 \mathrm{~mA})$.

Princippet i radiografianalyser er at røntgenstråler, der sendes gennem en sedimentskive vil absorberes forskelligt af materiale med forskeliig densitet. Ifølge Cohen (1952) vil strålingen kun absorberes stærkt af jernholdige mineraler, uafhængig af kemisk form og valens, og kun lidt af andre elementer. Det fremkomne billede vil således afspejle fordelingen af jern. 
APPENDIX 2

Tabel A: Bulkmineralogi.

Table A: Bulk mineralogy.

Tabel B: Lermineralogi.

Table B: Clay mineralogy.

Tabel C: Geokemiske data.

Table C: Geochemical data.

Tabel D: Data fra kornst $\varnothing$ relsesanalyse.

Table D: Data from grain size analysis. 
TABEL A: Bulkmi ralogi.

8 8 8 8 8 8 \& \& Cps.

Lerm. Kvarts K-Feld. Plag. Calc. Dolom. Pyr. Sid. Gibbsit

$\begin{array}{lrrrrrrrrr}\text { G-1 } & 46,6 & 36,7 & 1,6 & 7,5 & 3,2 & 1,4 & 2,9 & - & 60 \\ \text { G-2 } & 49,2 & 39,8 & 1,9 & 2,5 & 3,1 & 1,3 & 2,3 & - & 120 \\ \text { G-3 } & 56,8 & 32,0 & 2,9 & 1,7 & 3,4 & 0,7 & 2,4 & - & 150 \\ \text { G-4 } & 43,4 & 40,0 & 2,7 & 4,0 & 5,0 & 1,1 & 3,8 & - & 120 \\ \text { G-5 } & 43,7 & 45,9 & 1,7 & 1,9 & 2,4 & 1,1 & 3,4 & - & 80 \\ \text { G-6 } & 41,3 & 46,1 & 2,4 & 2,7 & 3,2 & 0,7 & 3,6 & - & 110 \\ \text { G-7 } & 42,5 & 45,0 & 2,4 & 2,6 & 2,5 & 1,3 & 3,6 & - & 100 \\ \text { G-8 } & 38,6 & 41,8 & 10,7 & 2,5 & 2,7 & - & 3,7 & - & 70 \\ \text { G-9 } & 53,2 & 35,4 & 2,1 & 2,3 & 4,2 & - & 2,9 & - & 150 \\ \text { G-10 } & 48,8 & 38,7 & 3,1 & 2,4 & 3,5 & 1,2 & 2,3 & - & 130 \\ \text { G-11 } & 38,6 & 48,3 & 2,9 & 3,1 & 4,0 & - & 3,0 & - & 80 \\ \text { G-12 } & 40,9 & 45,5 & 2,3 & 4,8 & 4,1 & - & 2,4 & - & 70 \\ \text { G-13 } & 35,4 & 51,9 & 2,9 & 1,7 & 3,7 & - & 4,5 & - & 80 \\ \text { G-14 } & 42,9 & 44,1 & 2,1 & 3,8 & 2,7 & - & 4,3 & - & 70 \\ \text { G-15 } & 41,3 & 46,8 & 3,7 & 2,0 & 2,7 & - & 3,5 & - & 70 \\ \text { G-16 } & 38,8 & 51,0 & 2,3 & 2,0 & 2,7 & 1,0 & 2,0 & - & 100 \\ \text { G-17 } & 41,4 & 47,5 & 3,6 & 1,8 & 2,4 & - & 3,4 & - & 90 \\ \text { G-18 } & 42,1 & 46,0 & 2,4 & 4,7 & 2,1 & - & 2,8 & - & 60 \\ \text { G-19 } & 43.5 & 44,4 & 4,1 & 2,7 & 1,9 & - & 3,4 & - & 100 \\ \text { G-20 } & 45,1 & 42,6 & 2,4 & 1,9 & 2,8 & - & 5,3 & - & 100 \\ \text { G-21 } & 49,9 & 37,1 & 2,9 & 2,4 & 2,1 & - & 5,5 & - & 110 \\ \text { G-22 } & 31,3 & 51,2 & 2,7 & 4,1 & 2,6 & 0,7 & 7,5 & - & 40 \\ \text { G-23 } & 38,5 & 47,8 & 3,8 & 3,6 & 2,3 & - & 4,0 & - & 100 \\ \text { G-24 } & 33,2 & 56,3 & 3,4 & 4,1 & 1,4 & - & 1,6 & - & 80 \\ \text { G-25 } & 44,1 & 45,8 & 2,2 & 1,8 & 2,1 & - & 4,1, & - & 100 \\ \text { G-26 } & 34,8 & 50,5 & 3,5 & 8,3 & 2,9 & - & - & - & 30 \\ \text { G-27 } & 24,2 & 66,4 & 4,8 & 3,1 & 1,5 & - & - & - & 90 \\ \text { G-A } & 17,5 & 21,8 & - & - & 4,7 & - & 2,7 & 53,3 & - \\ \text { G-B } & 19,4 & 12,2 & 1,7 & - & 33,3 & - & 1,7 & 31,7 & - \\ \text { G-C } & 17,3 & 20,1 & - & - & 4,0 & - & - & 58.6 & - \\ \text { G-B } & 21,6 & 36,8 & 3,7 & 2,0 & 2,4 & - & 2,6 & 31,0 & - \\ \text { GLS-1 } & 27,1 & 59,4 & 4,0 & 4,6 & 1,6 & - & 1,5 & 1,9 & 40 \\ \text { GLS-2 } & 31,8 & 57,4 & 3,4 & 3,0 & 1,3 & - & 1,7 & 1,3 & 50 \\ \text { G-13* } & 18,1 & 51,0 & 4,1 & 2,9 & 3,4 & 1,8 & 18,6 & - & - \\ \text { G-21** } & 34,9 & 51,1 & 3,1 & 3,4 & 1,5 & 0,7 & 5,3 & - & - \\ & & & & & & & & \end{array}$

Lerm = lermineraler, $\mathbf{R}$-Feld = kalifeldspat, Plag = plagioklas, Calc = Calcit, Dolom = dolomit, Pyr = pyrit, sid = siderit, $*=$ sandfraktion og $* *=$ siltfraktion. 
TABEL B: Lermineralogi.

\begin{tabular}{|c|c|c|c|}
\hline \multicolumn{2}{|c|}{ Kaolinit } & $8^{8}$ & $\begin{array}{c}8 \\
\text { Smektit }\end{array}$ \\
\hline G-1 & 38,4 & 42,7 & 18,9 \\
\hline G-2 & 37,5 & 41,0 & 21,5 \\
\hline G-3 & 52,5 & 31,1 & 16,4 \\
\hline G-4 & 46,4 & 37,6 & 16,0 \\
\hline G-5 & 37,9 & 35,4 & 26,6 \\
\hline G-6 & 47,4 & 33,0 & 19,6 \\
\hline G-7 & 43,5 & 31,5 & 35,0 \\
\hline G-8 & 36,2 & 30,9 & 32,9 \\
\hline G-9 & 38,6 & 32,3 & 39,1 \\
\hline G-10 & 36,6 & 31,3 & 32,1 \\
\hline G-11 & 43,5 & 27,9 & 28,6 \\
\hline G-12 & 39,1 & 33,5 & 27,4 \\
\hline G-13 & 40,0 & 30,6 & 29,4 \\
\hline G-14 & 44,4 & 31,9 & 23,6 \\
\hline G-15 & 45,4 & 33,2 & 21,3 \\
\hline G-16 & 35,3 & 33,7 & 31,0 \\
\hline G-17 & 37,3 & 34,8 & 27,9 \\
\hline G-18 & 39,5 & 37,5 & 23,1 \\
\hline$G-19$ & 43,1 & 33,2 & 23,7 \\
\hline$G-20$ & 45,5 & 26,4 & 28,1 \\
\hline G-21 & 42,9 & 29,2 & 28,0 \\
\hline G-22 & 46,6 & 32,2 & 21,2 \\
\hline G-23 & 48,3 & 32,3 & 19,4 \\
\hline G-24 & 51,6 & 37,7 & 10,7 \\
\hline G-25 & 45,3 & 31,2 & 23,5 \\
\hline G-26 & 42,4 & 42,9 & 14,7 \\
\hline G-27 & 56,8 & 40,1 & 3,1 \\
\hline
\end{tabular}


TABEL C: Geokemiske data.

\begin{tabular}{|c|c|c|c|c|c|c|c|c|c|c|c|}
\hline & $\begin{array}{l}8 \\
c\end{array}$ & $\stackrel{8}{\text { org.C }}$ & $\stackrel{8}{\mathrm{CaCO}_{3}}$ & $\begin{array}{l}8 \\
\mathrm{CaO}\end{array}$ & $\begin{array}{l}8 \\
\text { MgO }\end{array}$ & Mno & $\mathrm{K}_{2} \mathrm{O}$ & $\begin{array}{l}8 \\
\mathrm{Fe}\end{array}$ & $\begin{array}{l}8 \\
\mathrm{NaO}\end{array}$ & $\mathrm{Al}_{2} \mathrm{O}_{3}$ & s \\
\hline G-1 & 2,55 & 1,74 & 6,75 & 2,10 & 1,82 & 0,025 & 2,64 & 6,38 & 0,44 & 16,35 & 1,55 \\
\hline G-2 & 2,19 & 1,66 & 4,42 & & & & & & & & 1,26 \\
\hline G-3 & 1,89 & 1,50 & 3,25 & 1,13 & 1,69 & 0,028 & 2,47 & 5,21 & 0,33 & 22,79 & 1,05 \\
\hline G-4 & 2,24 & 1,69 & 4,58 & & & & & & & & 1,51 \\
\hline G-5 & 2,44 & 1,89 & 4,58 & & & & & & & & 1,73 \\
\hline G-6 & 2,19 & 1,79 & 3,33 & & & & & & & & 1,65 \\
\hline G-7 & 1,89 & 1,88 & - & & & & & & & & 1,73 \\
\hline G-8 & 2,33 & 2,02 & 2,58 & & & & & & & & 1,72 \\
\hline G-9 & 1,87 & 1,64 & 1,92 & 1,03 & 1,74 & 0,030 & 2,57 & 5,50 & 0,40 & 20,34 & 1,25 \\
\hline G-10 & 1,91 & 0,77 & - & & & & & & & & 1,06 \\
\hline G-11 & 2,20 & 1,69 & 4,25 & & & & & & & & 1,19 \\
\hline G-12 & 2,08 & 1,79 & 2,42 & & & & & & & & 1,22 \\
\hline G-13 & 2,44 & 2,36 & 0,67 & & & & & & & & 2,17 \\
\hline G-14 & 2,24 & 2,21 & 0,25 & 1,17 & 1,66 & 0,028 & 2,43 & 6,31 & 0,46 & 15,08 & 1,83 \\
\hline$G-15$ & 2,36 & 2,41 & 0,00 & & & & & & & & 2,02 \\
\hline G-16 & 2,10 & 1,93 & 1,42 & & & & & & & & 1.22 \\
\hline G-17 & 2,24 & 2,14 & 0,83 & & & & & & & & 1,65 \\
\hline$G-18$ & 1,80 & 1,59 & 1,75 & & & & & & & & 1,23 \\
\hline G-19 & 1,92 & 1,96 & 0,33 & 0,90 & 1,58 & 0,028 & 2,48 & 6,18 & 0,44 & 16,00 & 1,71 \\
\hline G-20 & 2,24 & 2,26 & 0,00 & & & & & & & & 2,51 \\
\hline$G-21$ & 3,00 & 2,80 & 1,67 & & & & & & & & 2,81 \\
\hline G-22 & 2,49 & 2,33 & 1,33 & & & & & & & & 4,08 \\
\hline G-23 & 2,12 & 1,80 & 2,67 & 0,63 & 1,45 & 0,036 & 2,55 & 5,63 & 0,46 & 16,78 & 1,85 \\
\hline G-24 & 1,44 & 1,28 & 1,33 & & & & & & & & 0,83 \\
\hline$G-25$ & 2,39 & 2,30 & 0,75 & & & & & & & & 1,93 \\
\hline$G-26$ & 0,79 & 0,68 & 0,92 & & & & & & & & 0,05 \\
\hline G-27 & 0,60 & 0,40 & 1,67 & & & & & & & & 0,03 \\
\hline
\end{tabular}

G-A

G-B

G-C

G-E

G-19 (lerfrak.)

G-23 (lerfrak.) $\begin{array}{lllllll}8 & 8 & 8 & 8 & 8 & 8 & 8 \\ \mathrm{Ca} & \mathrm{Mg} & \mathrm{Mn} & \mathrm{K} & \mathrm{Fe} & \mathrm{Na} & \mathrm{Al}\end{array}$ $\begin{array}{llllllll}6,00 & 3,31 & 0,167 & 0,55 & 25,56 & 0,17 & 1,94\end{array}$

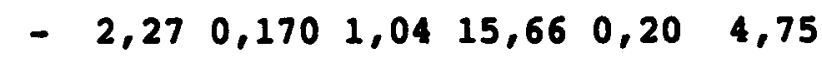
$\begin{array}{lllllllll}5,04 & 3,48 & 0,423 & 0,44 & 28,21 & 0,15 & 1,97\end{array}$ $\begin{array}{lllllllll}5,26 & 2,01 & 0,395 & 1,10 & 16,07 & 0,28 & 3,99\end{array}$ $\begin{array}{lllllllll}0,07 & 1,16 & 0,016 & 2,31 & 5,30 & 1,68 & 12,74\end{array}$ $\begin{array}{llllllll}0,06 & 1,09 & 0,018 & 2,22 & 4,87 & 2,18 & 13,04\end{array}$ 
TABEL D: Data fra kornstørrelsesanalyse.

\begin{tabular}{|c|c|c|c|c|c|c|c|c|c|c|}
\hline & 8 & 8 & & silt- & $\begin{array}{c}\text { og } \\
\text { umul }\end{array}$ & 8) & onen & & & \\
\hline & Sand & $\begin{array}{l}\text { Silt } \\
+ \text { ler }\end{array}$ & $>31,2$ & $>15,6$ & $>7,8$ & $>3,9$ & $>2,76$ & $>2,0$ & $<2,0$ & Med. \\
\hline-1 & 6,8 & 93,2 & 9,9 & 31,0 & 49,1 & 64,4 & 68,9 & - & - & 0,0072 \\
\hline G- 2 & 5,0 & 95,0 & 7,8 & 29,2 & 46,1 & 63,8 & 68,1 & 2,4 & 27,6 & 0,0069 \\
\hline G- 3 & 2,1 & 97,9 & - & 1,7 & 36,0 & 56 & 63,8 & 8,1 & 31,9 & .0052 \\
\hline G- 4 & 3,6 & 96,4 & 7,8 & 29,2 & 46,1 & 63,8 & 68,1 & 72,4 & 27 , & 29 \\
\hline G- 5 & 5,2 & 94,8 & - & 9,0 & 46,2 & 59,4 & 64,3 & 58,7 & 31 , & 0,0065 \\
\hline-6 & 5,8 & 94,2 & 12,2 & 5,5 & 8,4 & 0 & 7,5 & 1,4 & 18, & 0,0104 \\
\hline G- 7 & 9,9 & 90,1 & - & - & & - & 9 & 8,4 & 21, & - \\
\hline G- 8 & 4,2 & 95,8 &, 1 & 4,8 & & & 4 & 5 & 21 & 98 \\
\hline G- 9 & 3,3 & 96,7 & 1,5 & 5,0 & 8,5 & 3,6 & 8 & 9 & 26,1 & 15 \\
\hline-10 & 1,0 & 99,0 & 6,9 & 32,0 & 8,7 & 65 & 70,3 & 5,9 & 24,1 & 76 \\
\hline-11 & 3,1 & 9 & 18,9 & 7 & & & 78,5 & 2,5 & 17,5 & 0,0133 \\
\hline-12 & 7 & & 3 & & & & 5,6 & 8,5 & 21,6 & 0,0 \\
\hline G-13 & 7,0 & 93,0 & 9,1 & 2 & & & & & 16 & 0, \\
\hline-14 & 8,9 & 91,1 & 3,8 & 31,3 & 9 & 68 & & & 28 & 8 \\
\hline$G-15$ & 2,5 & 97,5 & 15,6 & 46,8 & 68,4 & 77 & 9,4 & 8 & & \\
\hline-16 & 5,2 & 94,8 & 6,5 & 38,6 & 59,3 & 73,1 & 73,7 & 78,4 & 21 & \\
\hline-17 &, 2 &, 8 & 7,4 & 37,0 & 60,6 & 74,6 & 76,1 & 81,1 & 18,9 & 0,0109 \\
\hline-18 &, 7 & & 21,5 & 0 & 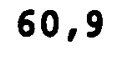 & 71,0 & 75,1 & 79,9 & 20,1 & 0,0117 \\
\hline-19 & 11,8 & 2 & נ, & & & & 10 & 1,1 & 18,9 & 0,0106 \\
\hline-20 & 2,1 & 97,9 & 4,9 & 32,9 & 52,7 & & 73,2 & 0,5 & 24,2 & 0,0088 \\
\hline-21 & 2,3 & 97,7 & 8 & 24,6 & 48,3 & 65 & 7 & 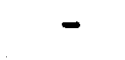 & - & 0,0 \\
\hline-22 & 7,0 & 93,0 & 26,5 & 56,2 & 68,0 & 77,9 & 80,8 & 84,1 & 15,9 & 1.0 \\
\hline-23 & 2,5 & 97,5 & 8 & 36,7 & 62,9 & 75,7 & 80,4 & 83,5 & 16,5 & 13 \\
\hline-24 & 6,7 & 93,3 & 33,7 & 58,9 & 72,7 & 82,5 & 84,5 & 87,5 & 12,5 & 04 \\
\hline-25 & 0,5 & 99,5 & 1,2 & 27,5 & 52,5 & 68,8 & 73,7 & 77,4 & 22,6 & 0,0086 \\
\hline-26 & 2,8 & 97,2 & 9,5 & 32,3 & 48,0 & 57,6 & 61,4 & 63,9 & 36,1 & 0,0069 \\
\hline-27 & 3,3 & 96,7 & 25,6 & 47,0 & 55,4 & 61,1 & 63,4 & 66,1 & 33,9 & 0,0125 \\
\hline
\end{tabular}


Tavle tekster

TAVLE $?$

Fig. 1-4: Radiografier. Gravegange i Gram leret. Skala 1:1. Mærket med GR1 til GR4 pá den lithologiske log.

Fig. 1-4: Radiographs. Burrows in the Gram Clay. Scale 1:1. Marked with GR1 to GR4 on the lithological log. 


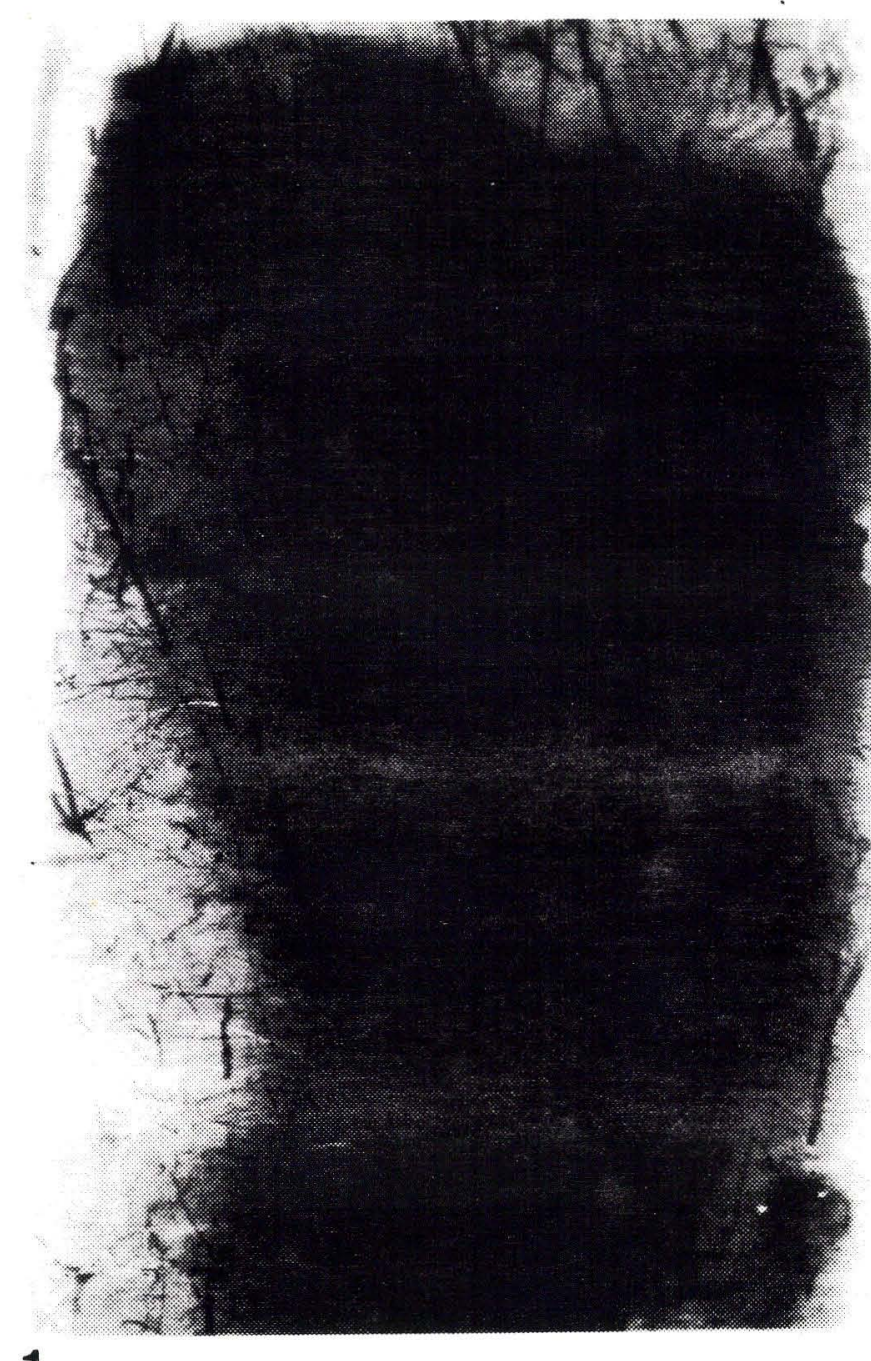

1

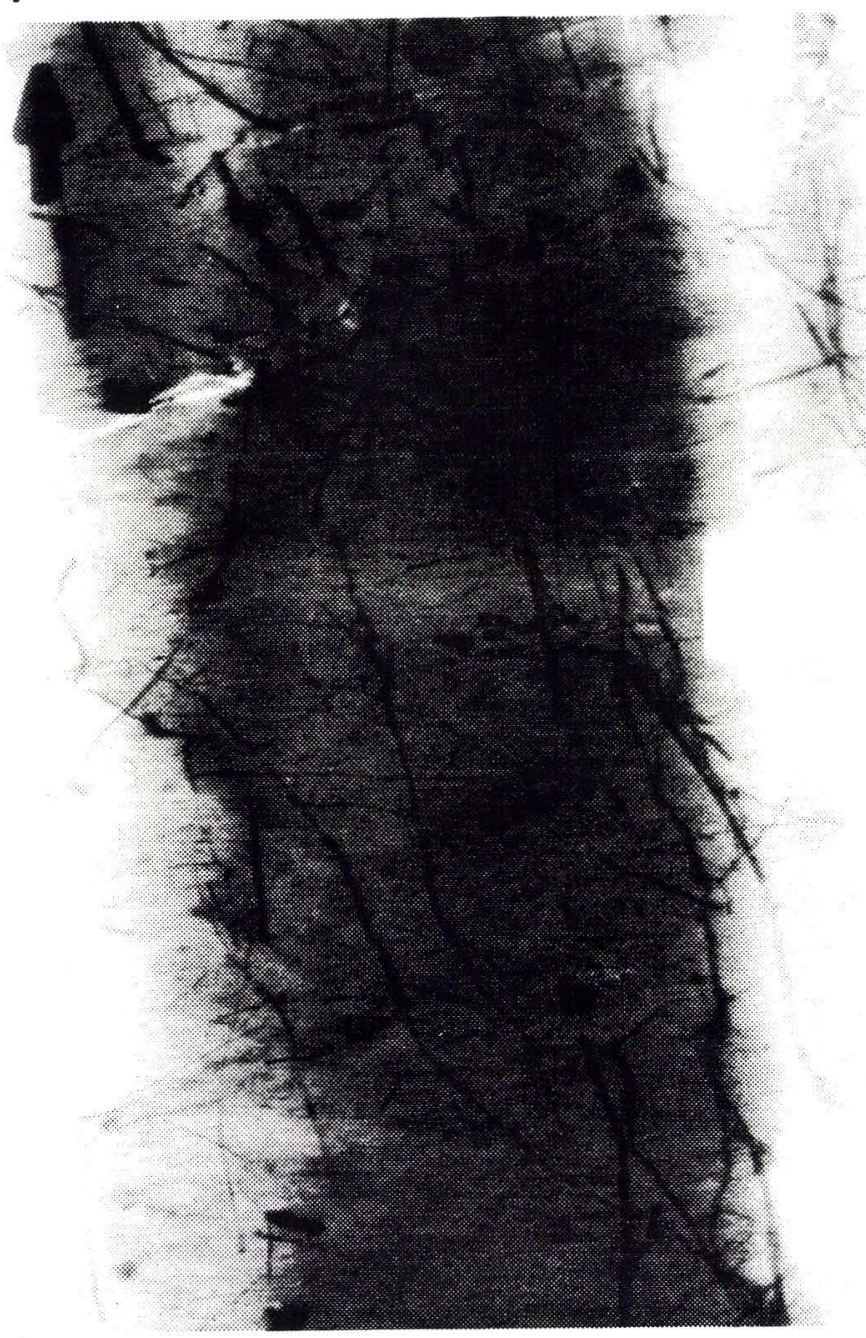

2

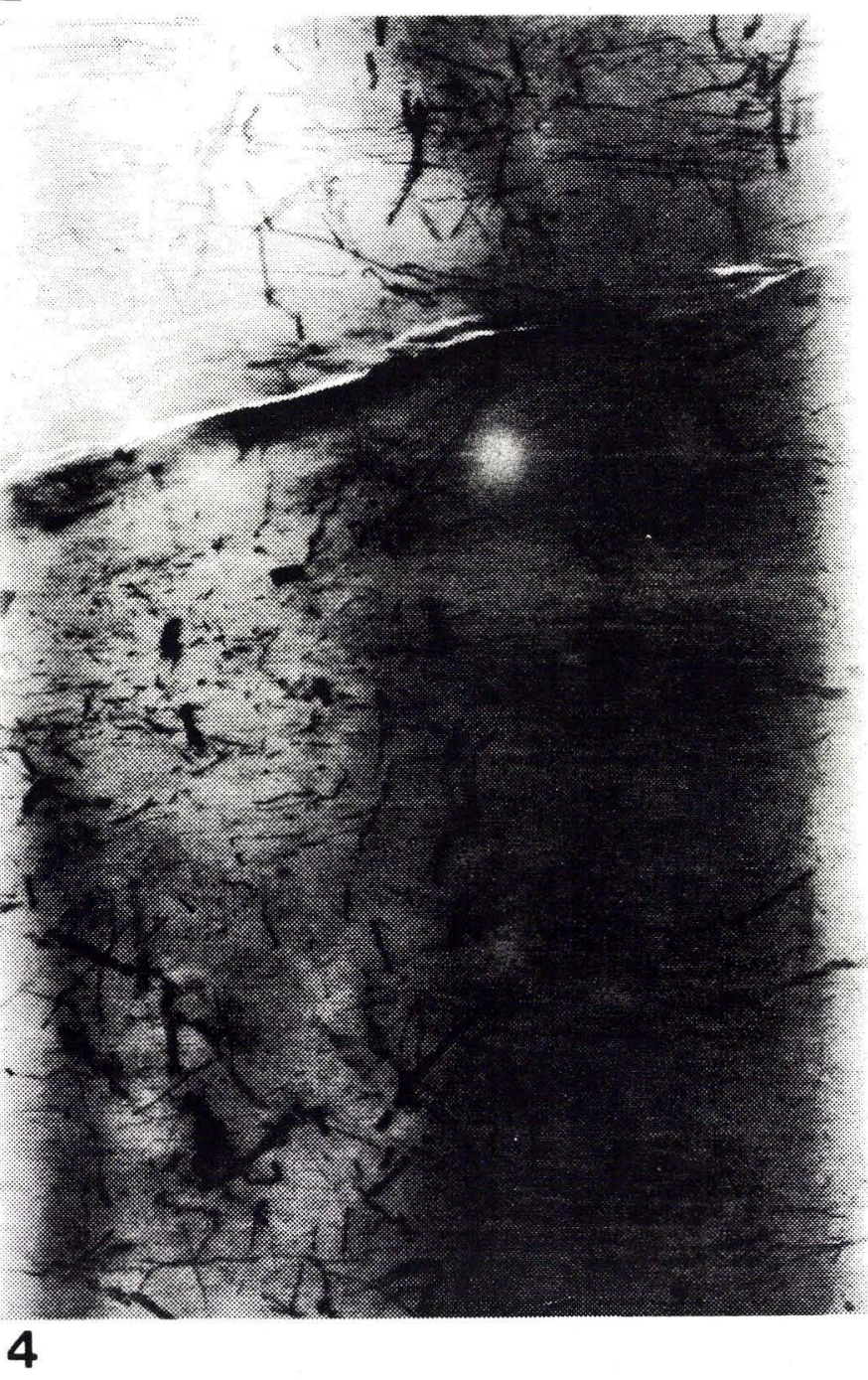


TAVLE 2

Fig. 1-2: Radiografier. Gravegange i Gram leret. Skala 1:1. Mærket med GR5 til GR6 på den lithologiske log.

Fig. 1-2: Radiographs. Burrows in the Gram Clay. Scale 1:1. Marked with GR5 to GR6 on the lithological log. 

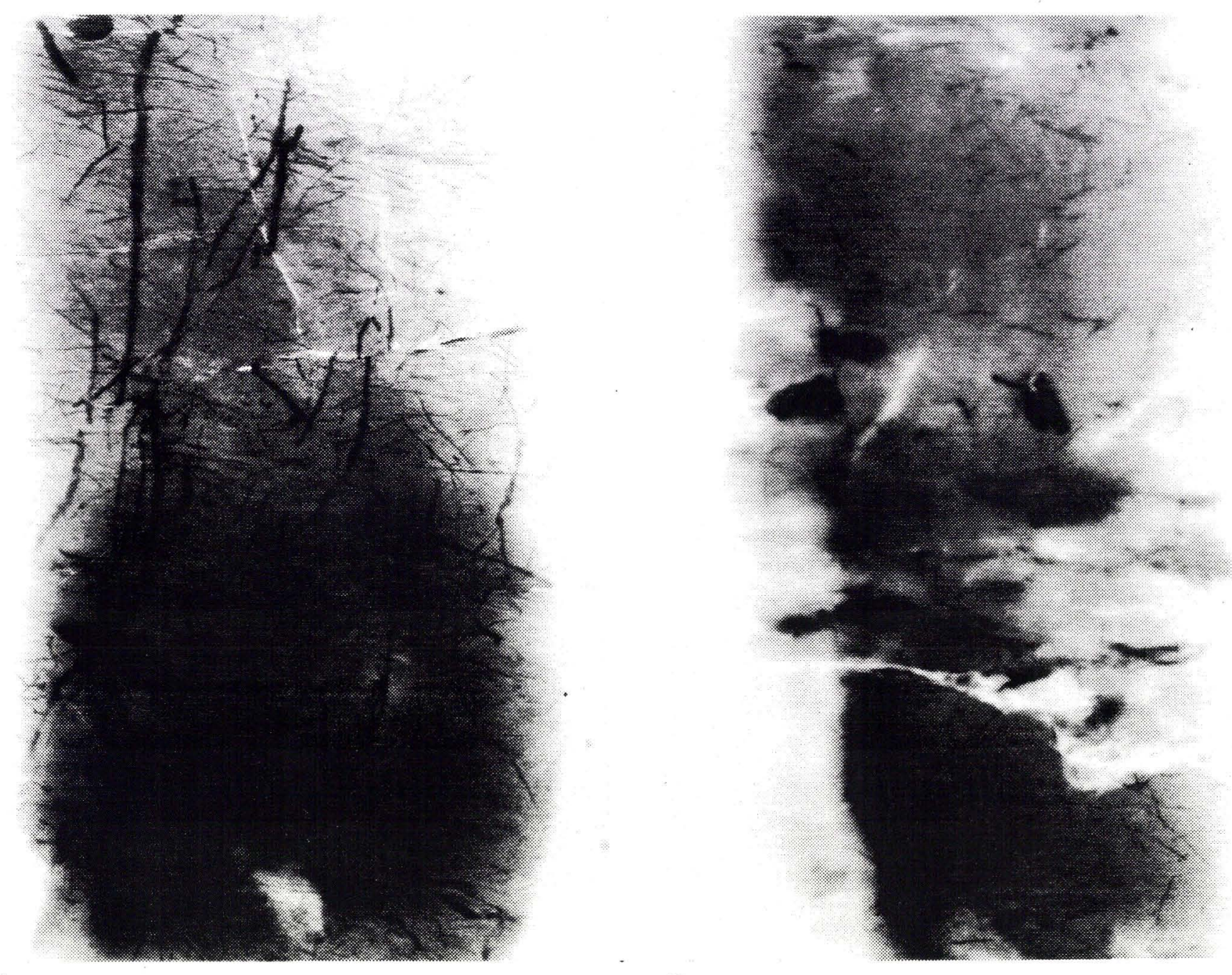

2 
Afhandlingen omfatter en sedimentologisk undersøgelse af det øvre miocæene Gram Ler på type lokaliteten.

Tolkningen er hovedsageligt baseret på mineralogiske og geokemiske analyser. Der er opstillet en dynamisk model for aflejringsmiljøet

(shelf miljø). Diagenesen er opdelt i 3 zoner; oxisk, anoxisk sulfidisk, og anoxisk metanisk zone. Disse zoner er relateret til den tidlige diagenese.

Miljøministeriet

Danmarks Geologiske Undersøgelse

Thoravej 8

DK 2400 København NV

Danmark

Telefon 31106600 